Zabytkoznawstwo i Konserwatorstwo XL, Toruń 2011

Monika Jakubek-Raczkowska

\title{
Uwagi o znaczeniu tzw. Pięknych Madonn w sztuce i religijności państwa zakonnego w Prusach ${ }^{\star}$
}

Diękne Madonny to jedna z najciekawszych i najbardziej rozbudowanych gatunkowo, a zarazem zwartych grup w rzeźbie późnośredniowiecznej. Zrodzone dzięki spontanicznemu rozwojowi religijności, finezyjne $\mathrm{w}$ formie, skomplikowane w treści, ponadczasowe w estetyce - od lat stanowią one przedmiot rozważań nad fenomenem kompleksowej formy obrazowej w sztuce gotyckiej. Dociekania te koncentrują się zasadniczo na dwóch zespołach problemów: ikonografii - typu - funkcji oraz genezy formalnej - stylu - atrybucji, z których pierwszy jest mniej wnikliwie rozpoznany․ Wyjątkowość Pięknych Madonn

* Studium typologii Pięknych Madonn w zachodnioeuropejskim kontekście porównawczym nie byłoby możliwe bez programu stypendialnego The Andrew W. Mellon Foundation i Fondation Maison des Sciences de L'Homme w Paryżu, z jakiego miałam zaszczyt skorzystać w 2007 r. Obydwu instytucjom, a także goszczącemu mnie Musée de Moyen Age w Paryżu, składam w tym miejscu serdeczne podziękowania. Punktem wyjścia weryfikacji znaczenia Pięknych Madonn była moja rozprawa: Rzeźba gdańska przełomu XIV i XV wieku, Warszawa 2006. Niektóre z poruszanych tu kwestii stylistycznych przedstawiłam już w artykule: Die "Schönen Madonnen” auf dem Gebiet des ehemaligen Deutschordensstaates Preußen - ein Beitrag zum Problem der künstlerischen Tradition im späten Mittelalter, w: Terra Sanctae Mariae. Mittelalterliche Bildwerke der Marienverehrung im Deutschordensland Preußen, Hg. G. Eimer, E. Gierlich, M. Müller, K. Pospieszny (Kunsthistorische Arbeiten der Kulturstiftung der deutschen Vertriebenen, Bd. 7), Bonn 2009, s. 227-254.

1 Z ważniejszych interpretacji warto wskazać: F. Holböck, Theologischer Hintergrund und Theologische Aussage der Schönen Madonnen, w: Ausstellung Schöne Madonnen 1350-1450, Hg. D. Grossmann, Salzburg 1965, s. 44-56; H. Beck, H. Bredekamp, Der internationale Stil, w: Kunst um 1400 am Mittelrhein. Ein Teil der Wirklichkeit, Ausstellungskatalog, Frankfurt am Main 1976, s. 1-29, zwł. s. 4-12; G. Winter, Zur Sinnbestimmung der „Schönen Madonnen” um 1400, „Giessener 
polega na tym, że próby interpretacji ich sensu teologicznego muszą wychodzić poza czysto ikonograficzne badania nad doborem symbolicznych motywów i uwzględniać także ujęcie formalne. Rodzi to konieczność definicji typu, która zyskała różnorakie, niekiedy rozbieżne ujęcia ${ }^{2}$. Decydujące dla dalszych badań wydają się propozycje Michaela Victora Schwarza ${ }^{3}$ i Wojciecha Marcinkowskiego ${ }^{4}$. Najważniejsze wskazywane przez nich desygnaty Pięknych Madonn są zbieżne. Za podstawowy należy uznać ich pełną plastyczność (u Marcinkowskiego, za Müllerem i Grossmannem, o cechach rzeźby architektonicznej, ale niezależnej od programów dekoracji ściennej ${ }^{5}$ ) oraz przynależność do stylu międzynarodowego około 1400 roku (u Schwarza - w Europie Środkowowschodniej ${ }^{6}$ ). Niewątpliwym wyróżnikiem jest też akcentowanie pewnych cech fizycznych ukazanych postaci (nowe, sensualne ujęcie kobiecości Madonny ${ }^{7}$, soteriologicznie pojęta, realna cielesność nagie-

Beiträge für Kunstgeschichte” 1983, nr 4, s. 1-22; H. Belting, Image et culte. Une histoire de l'image avant l'époque de l'art, Paris 1998, s. 586-589; N. Höcke-Groenewegen, Strategien der Devotion. Die Rhetorik mittelalterlicher Bildwerke des 14. Jahrhunderts im Kontext der zeitgenössischen Frömmigkeit am Beispiel der sogenannten Schönen Madonnen, Diss. Johann-Wolfgang-Goethe-Universität zu Frankfurt am Main 2005 (http://publikationen.ub.uni-frankfurt.de/volltexte/2008/5660/pdf/HoeckeGroene wegenNathalie.pdf). Osobno należy wymienić studium nt. ikonografii Madonny toruńskiej: J. Kruszelnicka, Dawny ołtarz Pięknej Madonny Toruńskiej, „Teka Komisji Historii Sztuki” 1968, t. IV, s. 5-85.

2 Zestawienie dotychczasowych propozycji zob. W. Marcinkowski, Co to jest Piękna Madonna?, w: Prawda i twórczość, red. M. Kapustka, Wrocław 1998, s. 39-53.

3 M. V. Schwarz, Schöne Madonna als komplexe Bildform: Prolegomena, w: Künstlerischer Austausch. Akten des XXVIII Internationalen Kongresses für Kunstgeschichte, hg. T. W. Gaethgens, Berlin 1993, Bd. 2, s. 89-95. Zob. także w wersji polskiej: idem, Piękna Madonna jako kompleksowa forma obrazowa. Zarys problematyki, „Dzieła i Interpretacje” 1993, nr 1, s. 87-93.

4 W. Marcinkowski, Co to jest Piękna Madonna?

5 T. Müller, Sculpture in the Netherlands, Germany, France und Spain 1400 to 1500, Harmondsworth 1966 (Pelican History of Art 25), s. 38; D. Grossman, Imago Pietatis, w: Stabat Mater. Maria unter dem Kreuz in der Kunst um 1400, Ausstellungskatalog, Salzburg 1970, s. 41-42; W. Marcinkowski, Co to jest Piękna Madonna?, s. 42-44.

6 M. V. Schwarz, Schöne Madonna als komplexe Bildform, s. 91.

7 U Schwarza określone wręcz jako „erotyczne”, ibidem, s. 90. Marcinkowski zwraca jednak uwagę, że cecha ta ma naturę ogólną i odnosi się do całego „stylu pięknego". W. Marcinkowski, Co to jest Piękna Madonna?, s. 42. 
go Dzieciątka) oraz ich wzajemnej relacji - Maria jest w nowy sposób aktywna (Marcinkowski ${ }^{8}$ ) i koncentruje się całkowicie na Dzieciątku $\left(\right.$ Schwarz $\left.{ }^{9}\right)$. O ile jednak dla Schwarza kwestia oryginalności tych rzeźb na tle wcześniejszej produkcji artystycznej tkwi w sferze socjologicznej (podjęcie elitarnych rozwiązań obrazowych poza środowiskiem dworskim), o tyle zdaniem Marcinkowskiego najistotniejszym wyróżnikiem jest ich pozaliturgiczny kontekst funkcjonalny.

Wobec pierwszorzędnego znaczenia Pięknych Madonn dla rozpoznania dróg ewolucji artystycznej w Europie Środkowej u progu XV wieku nie dziwi z kolei fakt, że stały się one także osią jednej z ważniejszych dyskusji w badaniach styloznawczych nad sztuką „jesieni średniowiecza"10. Mimo pozorów wyczerpania możliwości dyskursu ${ }^{11}$, krąg Pięknych Madonn i pod tym względem wciąż na nowo budzi kontrowersje i porusza wyobraźnię historyków sztuki, a coraz to nowe próby systematyki i atrybucji zacierają ostrość całościowego spojrzenia na sztukę lat około 1400 roku w tej części Europy ${ }^{12}$. Z uwagi na ten stan

8 W. Marcinkowski, Co to jest Piękna Madonna?, s. 46.

9 M. V. Schwarz, Schöne Madonna als komplexe Bildform, s. 90.

10 K. H. Clasen, Der Meister der Schönen Madonnen. Herkunft, Entfaltung und Umkreis, Berlin-New York 1974. Por. polemiczne recenzje: A. Kutal, Ein neues Buch über die Skulptur des Schönen Stils, „Umění“, 1975, t. 23, s. 544-567; R. Kahsnitz, Der Meister der Schönen Madonnen. Zu den Thesen von Karl Heinz Clasen, „Zeitschrift für Geschichte und Altertums Ermland” 1976, nr 38, 1976, s. 80-86; R. Suckale, „Kunstchronik” 1976, nr 29, H.8, s. 244-255; G. Schmidt, „Zeitschrift für Kunstgeschichte" $1978 \mathrm{nr}$ 41, s. 61-92; A. M. Olszewski, Uwagi o badaniach nad rzeźbq przełomu XIV i XV w. W związku z książka Karla Heinza Clasena, „Roczniki Sztuki Śląskiej” 1986, nr 14, s. 169-173. Zob. także J. Kębłowski, Dwie antytezy w sprawie tzw. Pięknych Madonn, w: Sztuka ok. 1400. Materiały Sesji SHS, Poznań, listopad 1995, t. I, red. T. Hrankowska, Warszawa 1996, s. 165-185.

11 Zob. streszczenie i podsumowanie sporu: Z. Kruszelnicki, „Piękne Madonny” - problem otwarty, „Teka Komisji Historii Sztuki” 1992, t. XVII, s. 31-103.

12 Nawet opracowania, towarzyszące wystawie sztuki praskiej doby Luksemburgów w Nowym Jorku (Metropolitan Museum of Art, 10 IX 2005-3 I 2006) i Pradze (Pražský Hrad 16 II-21 V 2006) otwierają nie tylko nową perspektywę, ale i nowe możliwości polemik. Zob. Prague. The Crown of Bohemia 1347-1447, ed. B. Drake Boehm i J. Fajt, New York 2006; Karl IV. Kaiser von Gottes Gnaden. Kunst und Repräsentation des Hauses Luxemburg 1310-1437 (kat. wystawy Praha, Správa Pražského hradu), hg. Jiří Fajt, unter Mitarbeit von Markus Hörsch, Andrea Langer, München-Berlin 2006. 
rzeczy, przedkładane studium nie ma na celu włączania w zastaną dyskusję dodatkowych argumentów natury ogólnej, gdyż - tu zacytuję za Schwarzem: „każda wypowiedź na temat tych rzeźb, wychodząca poza czystą inwentaryzację, posiada siłą rzeczy charakter hipotetyczny"13. Podejmując ponownie temat Pięknych Madonn, należy mieć tego świadomość. Niniejszy tekst wyrasta raczej z dyktowanej przez studia regionalne potrzeby ustosunkowania się do nowych, płynących z zewnątrz, propozycji badawczych.

Właśnie z punktu widzenia badań regionalnych dyskurs ten ma bowiem szczególne znaczenie. Istnienie dzieł stylu pięknego na obszarach odległych od serca ich kreacji (za które ostatnio coraz bardziej zdecydowanie uznaje się Pragę) zapewnia wielu ośrodkom ich miejsce $\mathrm{w}$ powszechnych badaniach nad fenomenem artystycznym lat około 1400 roku. Jak zauważył swego czasu Zygmunt Kruszelnicki, to właśnie problem Pięknych Madonn stanowi jedną z najbardziej europejskich kwestii w studiach nad sztuką państwa zakonnego w Prusach, a nawet więcej - nad "polskim średniowieczem artystycznym w ogóle” ${ }^{14}$. Jej ogniskową jest Piękna Madonna na konsoli z Mojżeszem, notowana od 1671 roku w kościele św. Jana w Toruniu (il. 1), wokół której koncentrował się niegdyś spór o tzw. „mistrza Pięknych Madonn”15. Rzeźba ta, choć zaginiona w czasie drugiej wojny światowej, pozostaje nieodmiennie najważniejszym - patrząc z perspektywy europejskiej - dziełem, zaistniałym w państwie zakonnym. Wymieniana jest $\mathrm{w}$ wielu istotnych, przekrojowych kompendiach, poświęconych sztuce gotyckiej czy rzeźbie średniowiecznej ${ }^{16}$, nieodłącznie zaś analizowana jest w tych opracowaniach, które zajmują się problemem stylu międzynarodowego. Z punktu widzenia wspomnianych na początku desygnatów, jest to w zasadzie jedyna „Piękna Madonna”, znana na terenach państwa zakonnego.

13 Cyt. za: M. V. Schwarz, Schöne Madonna als komplexe Bildform, s. 88.

14 Z. Kruszelnicki, „Piękne Madonny” - problem otwarty, s. 31.

15 Por. przyp. 11.

16 Przykładowo: Propyläen Kunstgeschichte, Bd. 7, Spätmittelalter und beginnende Neuzeit, red. J. Białostocki, Frankfurt/Main-Berlin-Wien 1972, s. 34; J. M. Liebmann, Die deutsche Plastik 1350-1550, Leipzig 1982, s. 108; R. Recht, La sculpture, w: R. Recht, A. Chatelet, Le monde gothique. Automne et renouveau, Paris 1988, s. $75-177$, zwł. s. 103. 
Oprócz dzieła toruńskiego do omawianego kręgu zaliczana jest także figura Matki Bożej z Dzieciątkiem z ołtarza różańcowego w kościele NMP w Gdańsku, określana mianem „Pięknej Madonny Gdańskiej” (il. 2). Włączenie jej do tej szczególnej grupy typologicznej ma charakter zwyczajowy i jest swego rodzaju nadużyciem, dokonanym u progu badań nad problemem Pięknych Madonn ${ }^{17}$. De facto, poza ogólnymi cechami stylu międzynarodowego, tylko nieliczne motywy - jak skupienie uwagi na atrybucie - łączą ją z tym fenomenem artystycznym ${ }^{18}$. Mimo to i ona znalazła w dotychczasowych badaniach nad kręgiem Pięknych Madonn swój europejski kontekst ${ }^{19}$. Obie rzeźby urosły poza tym do rangi lokalnych „ikon” sztuki około 1400 roku - dzieło toruńskie dla całego państwa zakonnego, figura gdańska dla Pomorza.

Najmniej znaną - a jednak, przynajmniej z punktu widzenia ewolucji sztuki państwa zakonnego, ważną - Piękną Madonną jest rzeźba w ołtarzu Bractwa Kapłańskiego NMP, również w kościele Mariackim w Gdańsku (il. 3). Ta z kolei figura postrzegana była dotąd na marginesie dwóch wspomnianych poprzednio; nie uwzględniano jej raczej w powszechnych badaniach nad problemem kręgu. Być może przyczyną jest fakt, że i ona „odstaje” od ikonograficznej tradycji Pięknych Madonn, powraca bowiem do pasywnej prezentacji Dzieciątka. Jednakże zarówno materiał i wymiary figury, jak i styl oraz kontekst funkcjonalny (o czym niżej), a także wzruszający liryzm

17 W. Pinder, Die deutsche Plastik vom ausgehenden Mittelalter bis zum Ende der Renaissance, 1. Teil (Handbuch der Kunstwissenschaft), Wildpark-Potsdam 1925, s. 240-241; K. H. Clasen, Die mittelalterliche Bildhauerkunst im Deutschordensland Preußen. Die Bildwerke bis zur Mitte des 15. Jahrhunderts, Berlin 1939, s. 145-159; A. Feulner, Der Meister der Schönen Madonnen, „Zeitschrift des deutschen Vereins für Kunstwissenschaft” 1943, nr 10, H.1/2, s. 19-48, zwł. s. 30.

18 O kontrowersjach, jakie budzi rzeczywista przynależność tej figury do kręgu Pięknych Madonn, pisałam obszernie wcześniej, por. M. Jakubek-Raczkowska, Rzeźba gdańska przełomu XIV i XV wieku, s. 74-76.

19 Przykładowo: A. Kutal, Ein neues Buch, s. 558; Z. Kruszelnicki, [hasło w:] Die Parler und der Schöne Stil 1350-1400. Europäische Kunst unter den Luxemburgern. Ein Handbuch zur Ausstellung des Schnütgen-Museums in der Kunsthalle Köln, Hg. Anton Legner, Bd. 2, Köln 1978, s. 521; R. Didier, R. Recht, Paris, Prague, Cologne et la sculpture de la seconde moitié du XIVe siècle. À propos de l'exposition des Parler a Cologne, „Bulletin Monumental” 1980, nr 88, s. 173-219, zwł. s. 190. 
i intensywność kontaktu z widzem - sankcjonują, według mnie, zaliczenie jej do tego kręgu ${ }^{20}$.

Wszystkie trzy dzieła, już przez samo zastosowanie kamienia należące na gruncie państwa zakonnego do nielicznych wyjątków, połączone zostały przez Karla Heinza Clasena nicią domniemanej zależności warsztatowej: obie figury gdańskie miałyby być własnoręcznymi dziełami „Mistrza Gdańskiej Pięknej Madonny”, ucznia i naśladowcy głównego "Mistrza Pięknych Madonn”21. Wydaje się jednak, iż żadna z nich nie była kreacją lokalną ziem dawnego państwa zakonnego ani też - że nie można ich bezpośrednio ze sobą powiązać. Wszystkie trzy prezentują bardzo wysoki poziom artystyczny, ale również odmienną koncepcję typologiczną.

I tak Madonna toruńska nie znajduje sobie równych w wysublimowanym połączeniu nienaturalnej pozy ciała, wdzięku gestu, delikatności twarzy oraz szlachetności Dzieciątka („antykizującego, stylizowanego i arystokratycznego"22). Skoncentrowanie uwagi Marii na Dzieciątku, a Dzieciątka na jabłku, wyklucza widza z intymnego kręgu pozornie naturalnej, a w swej istocie teologicznej "gry” atrybutem. Madonna z gdańskiego ołtarza Bractwa Maryjnego, o bardziej przysadzistych proporcjach, niosąca na ręce duże, pulchne niemowlę, stanowi wobec toruńskiej niemal antytezę. Gest prawej dłoni nadaje figurze większej ceremonialności; w zupełnie innych kategoriach potraktowany jest też związek postaci, które całkowicie ukierunkowane są na widza, przez co teologiczna prezentacja ma charakter „otwarty”. Madonna gdańska z kolei zadziwia monumentalnymi rozmiarami, rzadką w kręgu Pięknych Madonn kompozycją bryły i umieszczeniem Dzieciątka na prawej ręce; łączy też sztywność ujęcia, naturalizm szczegółów anatomicznych i ornamentalną stylizację. Postaci Marii i Jezusa skupione są przy tym całkowicie i wyłącznie na hieratycznej prezentacji atrybutu.

20 Por. bardziej szczegółowo M. Jakubek-Raczkowska, Rzeźba gdańska przełomu XIV i XV wieku, s. 110-112.

21 Zob. K. H. Clasen, Die mittelalterliche Bildhauerkunst, s. 132-159; idem, Der Meister, s. 33-35.

22 Z. Kruszelnicki, „Piękne Madonny” - problem otwarty, s. 89. 
U każdej z nich odmiennie pojęte jest nawet kryterium „piękna” fizjonomii - tak głęboko i symbolicznie wpisane w charakter tej grupy dzieł, niekiedy już w średniowieczu określanych jako pulchri ${ }^{23}$. Ta ich szczególna cecha winna być traktowana przede wszystkim w kategoriach teologicznych ${ }^{24}$. Pod względem formalnym wydaje się natomiast dziedzictwem stylu wykwintnego wieku XIII czy tendencji dworskich, rozwijanych pod wpływem francuskim w sztuce XIV-wiecznej. Zwraca jednak uwagę, że „dworski” ideał był z zasady rodzajem nienaturalnej stylizacji, podążającej za aktualnie respektowanym kanonem urody, a jego rozpowszechnianie się i standaryzacja wiodły ku stopniowej deformacji (jak w kręgu Madonn na lwach). W rzeźbie toruńskiej przeciwnie - niezrównane ponadczasowe piękno Marii i Dzieciątka nie jest „sztuczne”, jawi się raczej jako wynik podążania za naturą, tyle że pojętą w duchu augustyńskiej harmonii; nie bez powodu wywoływała antyczne skojarzenia ${ }^{25}$. Z drugiej strony, owa doskonałość jest tym właśnie, co Piękne Madonny odrealnia, czyni z nich transcendentny odblask boskości ${ }^{26}$. Toruńska Maria - tota pulchra, ideał Oblubienicy - jest kwintesencją tej idei, przewyższając pod tym względem inne przedstawicielki tej grupy.

Ujawnia to porównanie z figurą Bractwa Maryjnego z Gdańska. Pełne lirycznej słodyczy piękno, mimo pewnych podobieństw, zostało tu inaczej ujęte: oblicze Marii gdańskiej jest pełniejsze, czoło i broda - bardziej wypukłe, usta drobniejsze, wyraz twarzy - na-

23 Piękna Madonna z Krumłowa została określona jako pulchro opere imago virginis Marie. W. Marcinkowski, Przedstawienia dewocyjne jako kategoria sztuki gotyckiej, Kraków 1994, s. 44.

24 Zob. m.in. H. Beck, H. Bredekamp, Der internationale Stil, s. 5-6; N. HöckeGroenewegen, Strategien der Devotion, rozdział analityczny dotyczący kanonu urody Pięknych Madonn, z uwzględnieniem współczesnych analiz psychologicznych, s. 147-154 .

25 Kanonik Strzesz odnotował w 1671 r. dzieło mirae pulchritudinis et artificii supra ingenium Phidiae. Cyt za: J. Kruszelnicka, Dawny ołtarz Pięknej Madonny Toruńskiej, s. 10, przyp. 17. Kruszelnicki, omawiając Piękną Madonnę, pisał o „powiewie antyku”, „tchnieniu antycznej tradycji”, i zwracał uwagę na skojarzenia z praksytelesowskim posągiem Hermesa. Z. Kruszelnicki, „Piękne Madonny”-problem otwarty, s. 89 .

26 H. Beck, H. Bredekamp, Der internationale Stil, s. 6. 
iwny, wręcz dziecięcy. Ta szczególna cecha również ma swą teologię. Höcke-Groenewegen słusznie wiąże ją z ideą Niepokalanego Poczęcia i Dziewiczego Macierzyństwa $\mathrm{NMP}^{27}$ (Maria „dziecięca” to Maria bez skazy, sine macula). W tym zestawieniu słynna Madonna gdańska w ołtarzu różańcowym uderza odmiennością. Jej piękno jest inne - wyniosłe, dojrzalsze, a przez to bardziej tradycyjne (sięgające do „chłodnej” urody Madonn poprzedniej epoki); kanon idealizacji został przy tym przełamany licznymi naturalistycznymi szczegółami. Na pierwszy rzut oka ujawnia się więc inne źródło jej konwencji, a także, mniej chyba subtelny, zestaw znaczeń. U podstaw każdej z tych figur - mimo ich wspólnego korzenia stylowego - legły zatem odmienne tradycje artystyczne, wyznaczniki formalne oraz treści.

Clasenowskie atrybucje miały jednak swą przyczynę i uzasadnienie. Wszystkie te figury reprezentują nie tylko wspólny idiom stylistyczny, łączy je także nowy na ziemiach państwa zakonnego modus ikonograficzno-funkcjonalny. To on właśnie, wyróżniając te Madonny na tle wcześniejszej produkcji rzeźbiarskiej regionu, samorzutnie prowadził do kojarzenia ich z jedną grupą warsztatową. Celem niniejszego artykułu jest wyartykułowanie obu tych problemów. Po pierwsze - czym były Piękne Madonny w religijności krzyżackich Prus i jakie postawy wyrażały? Po drugie - czy państwo zakonne faktycznie miało swój udział w kształtowaniu fenomenu Pięknych Madonn, czy też było raczej jego odbiorcą? Czy rzeczywiście można mówić o typie „pruskośląskim”, podkreślając tak silnie kreatywność tych ziem na przełomie XIV i XV stulecia?

\section{Piękne Madonny jako koncepcja typologiczna na tle sztuki państwa zakonnego w Prusach}

Szczególną cechą Pięknych Madonn jest ich sensualny naturalizm i nuta melancholijnej intymności, czytelna nawet u obu figur gdańskich, choć Maria i Jezus są w nich dość zdystansowani - w stosunku do widza i do siebie nawzajem. Pod względem owego niewymuszonego liryzmu

27 N. Höcke-Groenewegen, Strategien der Devotion, s. 150. 
oraz pozornego psychologizmu obserwacji, Piękne Madonny stanowiły zjawisko indywidualne na tle wcześniejszych wyobrażeń maryjnych, zaistniałych w ramach bujnego kultu NMP na ziemiach państwa zakonnego ${ }^{28}$. Wobec dobrze rozpoznanych zadań, jakie krzyżacka propaganda władzy stawiała czci Matki Bożej ${ }^{29}$, nie dziwi fakt, że aż do pojawienia się nowych rozwiązań stylu międzynarodowego, przeważał w sztuce Prus tradycyjny, XIII-wieczny obraz majestatu Marii-Królowej. Za paradygmat tego sposobu wyobrażenia można uznać „Kolosa malborskiego”, figurę krzyżackiej patronki, symboliczną w swej funkcji "mistycznego puklerza" ${ }^{30}$. Zasadniczą cechą tego ujęcia była hieratyczna, ceremonialna prezentacja całkowicie lub częściowo odzianego Dzieciątka, podtrzymywanego nienaturalnie wysoko (jak przykładowo u Madonny z Brzozia, Bisztynka, Dobrzyków czy w toruńskim kościele św. Jakuba), utrzymująca się jeszcze u progu XV wieku (np. figura z ołtarza dzierzgońskiego w Muzeum Narodowym w Gdańsku). Poza tym, maryjna ikonografia w Prusach była zdominowana przez wizerunek Marii tronującej - jako Bogarodzicy (z Dzieciątkiem na kolanach) lub jako Eklezji (u boku Chrystusa-Oblubieńca). Wyobrażenie majestatu i przywileju Theotokos znalazło swój najpełniejszy wyraz teologiczny w tzw. Madonnach szafkowych, chyba jedynej oryginalnej kreacji mariologicznej w sztuce państwa zakonnego ${ }^{31}$.

Zwraca jednak uwagę, że Piękne Madonny nie były jedynym typem przedstawieniowym, jaki pod koniec XIV wieku przełamał w Pru-

28 Szczególnie pomocne w ocenie skali zjawiska są analizy Rozynkowskiego, omawiające różne aspekty maryjnego kultu w Prusach - wspomnienia w kalendarzu liturgicznym, obecność w patrociniach, miejsca pielgrzymkowe, toponimy. W. Rozynkowski, Omnes Sancti et Sanctae Dei. Studium nad kultem świętych w diecezjach pruskich państwa zakonu krzyżackiego, Malbork 2006.

29 M. Dygo, O kulcie maryjnym w Prusach Krzyżackich w XIV i XV w., "Zapiski Historyczne" 1987, t. 52, z. 2, s. 5-36.

30 M. Kutzner, Propaganda władzy w sztuce Zakonu Niemieckiego w Prusach, w: Sztuka w kręgu zakonu krzyżackiego w Prusach i Inflantach (Studia Borussico-Baltica Torunensia Historiae Artium, 2), red. M. Woźniak, Toruń 1995, s. 17-66, zwł. s. 59. Zob. też M. Dygo, O kulcie maryjnym w Prusach Krzyżackich w XIV i XV w., s. 9.

31 Zob. R. Ciecholewski, Problematyka badawcza pomorskich Madonn szafkowych, „Studia Pelplińskie” 1977, nr 8, s. 127-157; idem, Polityka krzyżacka przełomu XIV i XV wieku w świetle ikonografii malowidet na „skrzydłach” pomorskich Madonn szafkowych, „Studia Pelplińskie” 1980, nr 11, s. 253-270. 
sach ukonstytuowany wcześniej zespół hieratycznych wyobrażeń. Paralelnym zjawiskiem były rzeźby z kręgu Madonn na lwach - powstały wcześniej, ale trwający równolegle idiom stylowy, który również wpisywał się w nowy, „uczłowieczony” wymiar kultu maryjnego. Wystarczy porównać tronującą Madonnę w Mątowach Wielkich (około 1350 r.) z naiwnie uczuciowym wyobrażeniem uśmiechniętej Marii, piastującej Dzieciątko, pochodzącej z Jeziernika (ostatnia ćwierć XIV wieku, Muzeum Narodowe w Gdańsku) czy wspomnianą Madonnę malborską (około 1340 r.) z depczącą po lwie Madonną w Lubieszewie (około 1375 r.). Przesadna stylizacja wielu prowincjonalnych figur z kręgu warsztatowego Madonn na lwach doskonale wpasowała się zresztą w potrzeby pruskiej prowincji, stąd rozwijał się on i manieryzował jeszcze w głąb pierwszej połowy XV stulecia. Zaistnienie nowej formuły mogło wiązać się z poświadczonym w studiach nad późnośredniowieczną religijnością wzrostem czci maryjnej pod koniec XIV stulecia, przejawiającym się na ziemiach krzyżackich na przykład w rozwoju lokalnych pielgrzymek do miejsc związanych z kultem NMP (jak sanktuarium w Łąkach Bratiańskich) ${ }^{32}$.

Fenomen odrębności Pięknych Madonn nie tkwi więc wyłącznie w warstwie obrazowej. Tym natomiast, co zwraca szczególną uwagę $\mathrm{w}$ przypadku wszystkich dzieł $\mathrm{z}$ tego kręgu, jest ich przestrzenna autonomia, uzyskana poprzez nadanie postaciom naturalnego wolumenu (bez spłaszczania ich tylnej partii) oraz plastyczne opracowanie ze wszystkich stron. Pod tym względem Piękne Madonny stanowiły wśród maryjnych wyobrażeń w Prusach ujęcie nowe. Podczas gdy rzeźby z Lubieszewa, Jeziernika, Niedźwiedzicy, należące niegdyś do szafiastych nastaw ołtarzowych, poddane były liturgicznemu rytuałowi revelatio (a więc ich egzystencja w przestrzeni kościoła miała charakter tymczasowego misterium, związanego z oficjalnym kultem) ${ }^{33}$, Piękne Madonny - opracowane krągło - musiały wiązać się ze szczególnymi formami późnośredniowiecznej religijności. Oczywiście, podważając ich wyjątkowość, można by wskazać nieliczne wcześniejsze przykłady

32 W. Rozynkowski, Omnes Sancti, s. 202.

33 Do dziś wiele z nich pozostaje w kulcie jako „przedstawienia łaskawe”, np. w sanktuariach w Piasecznie, Rywałdzie, Lubieszewie. 
rzeźb maryjnych - zapewne kultowych, które także nie należały raczej do zamykanych retabulów, lecz najprawdopodobniej zachowywały pewien stopień autonomii w tabernakulach na ołtarzach ${ }^{34}$. Jak zauważył jednak Marcinkowski, większość z Pięknych Madonn pierwszej generacji nie tylko pozbawiona była ram retabulum, ale też $\mathrm{w}$ ogóle wyjęta $\mathrm{z}$ kontekstu altarii. Z tej perspektywy stanowią one ukoronowanie ewolucji maryjnych wizerunków kultowych w stronę spontanicznej dewocji, stojąc zarazem o krok od przewartościowania tej funkcji.

Od przełomu XIII i XIV wieku, postępując za żywiołowym rozwojem czci maryjnej i mistyki, sztuka zachodnia wytworzyła w obrębie tematu maryjnego szereg homogenicznych stylowo zespołów rzeźbiarskich, których liczebność i różnorodność, a także samodzielność plastyczna świadczą o nowych potrzebach w obrębie praktyki religijnej, jakim służył zapewne intymny wymiar obrazowy ${ }^{35}$. Figury te były z jednej strony odpowiedzią Kościoła na wzrost spontanicznego kultu maryjnego, z drugiej - stanowiły próbę unormowania go przez przypisanie im kontekstu liturgicznego (usytuowanie w obrębie ołtarza, nadanie odpustu) ${ }^{36}$. Nie można wykluczyć, że „oficjalna” kultowość takich przedstawień (związek z ołtarzem) nie musiała być równoznaczna $z$ pozbawieniem ich wizualnego oddziaływania $\mathrm{w}$ obrębie pobożności prywatnej. Ich kompozycyjne ukierunkowanie na widza, przełamywanie majestatycznej frontalności, czułe gesty Dzieciątka - mogły wiązać się z wewnętrznymi, indywidualnymi praktykami religijnymi ${ }^{37}$. W grupie Pięknych Madonn doszło natomiast do całkowi-

34 Tak było zapewne w przypadku Madonny z Gruty (koniec XIII w.), Ostromecka czy Mątowów (przed połową XIV w.).

35 Do takich przedstawień należą m.in. Madonny Ile-de-France (z charakterystycznym gestem sięgania Dzieciątka do policzka Matki, jak Madonna z Maisoncelles w paryskim Luwrze) czy przepełnione smutkiem Madonny lotaryńskie, pod wieloma względami zapowiadające „styl Pięknych Madonn” (np. figury w kościele św. Marcina w Bayel, św. św. Piotra i Pawła w Morhange czy św. Marcina w Maxeville).

36 Zob. na ten temat A. Köstler, Die lothringische Skulptur als Kultbild, w: Lothringische Skulptur des 14. Jahrhunderts, (Katalog wystawy Saarlandmuseum 1 V-30 VII 2006 r.), red. R. Melcher, Petersberg 2006, s. 18-29.

37 O rodzaju „wewnętrznych” i „zewnętrznych” praktyk kultowych w Kościele katolickim (w oparciu o naukę św. Tomasza z Akwinu) por. W. Urbanowicz, Religijność a praktyki religijne, „Ateneum Kapłańskie” 1960, nr 60, z. 306, s. 60-70. 
tego wyzwolenia się „kultowości” figur z zależności liturgicznej; jak stwierdził Marcinkowski, stawały się one samodzielnymi ośrodkami spontanicznego kultu w obrębie świątyni, które kościół tymczasowo sankcjonował odpustami ${ }^{38}$ (co było zwyczajową praktyką w przypadku tzw. Ablaßbilder ${ }^{39}$ ). Konglomerat ich treści mógł wiązać się z praktyką komunii św. duchowej - zdaniem Marcinkowskiego wyobrażenie Marii, która staje się ołtarzem, niosącym ciało Chrystusa, nie musiało stać na ołtarzu ${ }^{40}$.

Trudno nie zgodzić się z dokonaną przez tego badacza analizą najstarszego podtypu czeskich Madonn - tych w geście ostensio. Zwraca jednak uwagę, że żadna $\mathrm{z}$ omawianych figur, $\mathrm{z}$ terenów państwa zakonnego, nie podążała zbyt dosłownie za tak pojętą, eucharystyczną symboliką (jej jedynym kryterium byłaby tu nagość Dzieciątka). U żadnej z nich nie występuje charakterystyczny motyw „zagłębiania” się palców Marii w ciało Dzieciątka, kojarzony przez Becka i Bredekampa z woskiem świecy ofiarnej, a przez to - z Transsubstancjacją ${ }^{41}$. Wielowątkowe przesłanie Madonny toruńskiej na konsoli z Mojżeszem miało zdecydowany kontekst mariologiczny - Nowa Ewa symbolizowała tu Kościół, wyrastający z Synagogi i tryumfujący nad nią ${ }^{42}$. U Madonny Bractwa Maryjnego gest ostensio zastąpiony jest przez tradycyjną prezentację. U Pięknej Madonny Gdańskiej - najmniej wśród nich „kanonicznej” - znikła nawet owa sensualna nagość, konkretyzująca ciało Chrystusa (Dzieciątko owinięte jest częściowo draperią). Trudno więc dowieść, czy którakolwiek z nich miała faktycznie eucharystyczne zabarwienie ideowe; na pewno nie było ono tak ewidentne, jak u czeskich Madonn, których typologia także znalazła $\mathrm{z}$ czasem drogę do sztuki państwa

38 W. Marcinkowski, Co to jest Piękna Madonna?, s. 45.

39 W wielu przypadkach nadawanie odpustu wizerunkowi było nie - przyczyną samorzutnego kultu, lecz jego wynikiem. Por. na ten temat: H. Dünniger, Ablaßbilder. Zur Klärung der Begriffe „Gnadenbild” und „Gnadenstätte”, w: idem, Wallfahrt und Bilderkult. Gesammelte Schriften, hg. W. Brückner, J. Lenssen, K. Wittstadt, Würzburg 1995, s. 353-392, zwł. s. 357.

40 W. Marcinkowski, Co to jest Piękna Madonna?, s. 45.

41 H. Beck, H. Bredekamp, Der internationale Stil, s. 8-9.

42 J. Kruszelnicka, Dawny ołtarz Pięknej Madonny Toruńskiej, s. 15-30. 
zakonnego ${ }^{43}$. Mogły mieć natomiast pozaliturgiczną funkcję, a dzięki nowemu, uczuciowemu sposobowi ujęcia - podobnie jak inne Piękne Madonny - służyć indywidualnej dewocji.

Problem kontekstu liturgicznego wszystkich trzech figur sprawia jednak interpretacyjne trudności. Piękna Madonna Gdańska od XVI wieku znajduje się w baldachimowej oprawie, zwanej z uwagi na ikonografię „retabulum różańcowym” ${ }^{\text {. }}$. W 1689 roku Frisch wzmiankował figurę (traktując tę jej obudowę jako ikonograficzny „dodatek”) przy południowym filarze skrzyżowania $n^{4} w^{45}$. Prawdopodobnie została ona wtórnie związana z altarią Matki Boskiej Różańcowej ufundowaną w 1499 roku na miejscu wcześniejszego ołtarza Krzyża Świętego, która należała do bractwa różańcowego ${ }^{46}$. Możliwe jest więc, że przed wprowadzeniem do retabulum, funkcjonowała wcześniej jako samodzielny wizerunek, otaczany czcią ${ }^{47}$. W przypadku rzeźby stojącej w ołtarzu

43 Zob. niżej, por. także M. Jakubek-Raczkowska, Rzeźba gdańska przełomu XIV i XV wieku, s. 125-128.

44 O obudowie Pięknej Madonny Gdańskiej por. K. Zalewska, Modlitwa i obraz. Średniowieczna ikonografia różańcowa, Warszawa 1999, s. 63-74.

45 Bej diesem Pfeiler stehet ein Marienbild, welches auff den Armen das Kind Jezus hält. Umb daßselbe ist die Passionis Christi auff etzlichen Taffeln in dem Rosenkrantz zu sehen. G. Frisch, Der Sankt Marien Pfarrkirchen in Dantzig inwendige Abriss. Beschreibung der Oberpfarrkirche zu Sankt Marien in Danzig und der inneren Merkwürdigkeiten derselben, vorzüglich des berühmten Altargemäldes auf welchem das Jüngste Gericht abgebildet ist, Danzig 1689; oprac. K. Cieślak, Fundacja Ferberowska, Bibliotheca Historica Gedanensis, Vol.1, Gdańsk 1999, s. 32.

$46 \mathrm{Na}$ temat fundacji ołtarza i wikarii zob. P. Oliński, Fundacje mieszczańskie $w$ miastach pruskich $w$ okresie średniowiecza i na progu czasów nowożytnych, Toruń 2008, s. 247-250.

47 Pierwotna funkcja nastawy różańcowej jest w literaturze kwestią dyskusyjną. Kutzner zakłada tożsamość retabulum z Piękną Madonną i ołtarza bractwa różańcowego, który uznaje za służący wyłącznie dewocji. M. Kutzner, Die spätmittelalterliche Ausstattung der Marienkirche als Ausdruck der intelektuellen Empfingsamkeit und Religiösität der Danziger Bürger im ausgehenden Mittelalter, w: Die sakrale Backsteinarchitektur des südlichen Ostseeraums: der theologische Aspekt, Hg. G. Eimer, E. Gierlich, Berlin 2000, s.131-154, zwł. s. 136; K. Zalewska uważa, że użyty przez Frischa termin Marienbild może oznaczać, iż w kościele protestanckim nastawa różańcowa straciła swą pierwotna funkcję, lub że od początku była tylko obudową dla posągu kultowego, natomiast nie łączy jej z ołtarzem bractwa różańcowego w kościele Mariackim, sugerując nawet pochodzenie Madonny i jej obudowy z franciszkańskiego kościoła św. Trójcy. K. Zalewska, Modlitwa i obraz, s. 65. Z kolei K. Cieślak opowiada 
Bractwa Maryjnego można również hipotetycznie założyć jej pierwotną autonomię ${ }^{48}$. Problem rodzi natomiast retabulum Pięknej Madonny Toruńskiej, opisane przez kanonika Strzesza w 1671 roku i przeanalizowane przez Janinę Kruszelnicką jako całość ideowa, odpowiadająca treścią przekazowi samej figury ${ }^{49}$. Trudno nie zgodzić się, że rozpoznane przez badaczkę elementy obrazowe tworzyły spójną koncepcję mariologiczną. Argumentacja na rzecz pierwotnej integralności kompozycji - u progu XV wieku - budzi jednak wątpliwości. Pomijając fakt, że przytoczone przez Kruszelnicką analogie wśród „tablicowych” nastaw francuskich nie brzmią przekonywająco ${ }^{50}$, a połączenie drewna i kamienia nadawało całej kompozycji cech wtórności, najważniejsze wydaje się, że retabulum to nie miało tradycyjnych cech nastawy skrzydłowej. Pod tym względem byłby to ewenement na ziemiach Zakonu. Nie wyrokując ostatecznie o metryce owej kompozycji (choć skłaniałabym się ku odrzuceniu jej datowania na XV wiek i - za Paatzem - uznaniu jej za wtórne zestawienie średniowiecznych fragmentów o różnej

się za związkiem nastawy z kościołem NMP, ale za Zalewską przyjmuje możliwość fundacji ołtarza przez Svenichena; uważa, że umieszczenie otaczanego czcią wizerunku Madonny w różańcowej obudowie mogło być katolicką reakcją na wydarzenia lat 20. XVI w., których impet był skierowany przeciw kultowi maryjnemu. K. Cieślak, Między Rzymem, Wittenberga a Genewa. Sztuka Gdańska jako miasta podzielonego wyznaniowo, Wrocław 2000, s. 100.

48 Próby wiązania figury $\mathrm{z}$ ołtarzem baldachimowym św. św. Kosmy i Damiana nie wydają mi się przekonywające. Być może retabulum, w którym znajduje się dziś, było jej pierwotną oprawą, wykonaną przy okazji renowacji kaplicy Bractwa NMP w 1478 r. Wprowadzenie figury w obręb retabulum mogło mieć na celu nie tyle pozbawienie jej pozaliturgicznego kontekstu, co przydanie oprawy, odpowiedniej do rangi dzieła. Więcej na ten temat: M. Jakubek-Raczkowska, Rzeźba gdańska przełomu XIV i XV wieku, s. 113-114.

49 J. Kruszelnicka, Dawny ołtarz Pięknej Madonny Toruńskiej, s. 66-67. Autorka, mając na uwadze kryteria ikonograficzne, uznała analizowany przez siebie ołtarz za nierozerwalną całość ideową z 1 poł. XV w.

50 Na co zwrócił uwagę nawet Zygmunt Kruszelnicki; idem, „Piękne Madonny” - problem otwarty, s. 85. Także proponowana przez tego autora analogia w ołtarzu w Verchen (ibidem, s. 85-88) też nie wydaje mi się przekonywająca - w późnogotyckiej szafie retabulum umieszczone są wprawdzie figury o dużej autonomii, ale wykonane $\mathrm{z}$ drewna. Trudno wyobrazić sobie ich uprzednie funkcjonowanie bez tego typu oprawy snycerskiej. 
proweniencji ${ }^{51}$ ), należy zwrócić uwagę na niezwykły sposób ekspozycji figury Marii. Stojąc na swej konsoli - nawet usytuowanej ponad liturgiczną mensą, nawet $\mathrm{w}$ otoczeniu innych przedstawień - Piękna Madonna była de facto dekoracją architektoniczną i podlegała kryterium stałej dostępności, jakie Wojciech Marcinkowski wyróżnił, definiując przedstawienia dewocyjne ${ }^{52}$. Kontekst kultowy tej rzeźby mógł więc swobodnie zmieniać się z zewnętrznego (obrzęd liturgiczny) na wewnętrzny (modlitwa, medytacja, komunia św. duchowa), któremu z pewnością służyła psychologiczna sugestywność samego wyobrażenia.

Dewocyjną (medytacyjną) funkcję Pięknych Madonn wyakcentowała ostatnio Höcke-Groenewegen, analizując treści poszczególnych figur $\mathrm{w}$ szerokim kontekście średniowiecznej mistyki ${ }^{53}$. Piękne Madonny - w których splotła się myśl o Inkarnacji, Transsubstancjacji, Niepokalanym Poczęciu NMP i mistycznych zaślubinach Oblubienicy i Oblubieńca - wyrosły jej zdaniem z idei Imitatio Christi et Mariae. Ich przemyślana struktura wizualna miała służyć dążności do unii mistycznej poprzez kontemplację w ramach „mistyki codzienności” - postawie, promowanej przez devotio moderna (tu w znaczeniu ogólnej tendencji w duchowości). Zapewne przedmiotowy naturalizm Pięknych Madonn wiązał się z rolą zmysłowego spojrzenia jako ważnego momentu w średniowiecznej praktyce modlitewnej ${ }^{54}$, przesycający je klimat intymno-

51 W. Paatz, Prolegomena zu einer Geschichte der deutschen spätgotischen Skulptur im 15. Jh., Heildelberg 1956, s. 31.

52 W. Marcinkowski, Przedstawienia dewocyjne jako kategoria sztuki gotyckiej, s. 48.

53 N. Höcke-Groenewegen, Strategien der Devotion. Autorka szeroko analizuje treści ideowe Pięknych Madonn (s. 117-228) oraz współczesne ich powstaniu aspekty funkcjonowania obrazu w służbie pobożności (s. 234-272). Zob. szczególnie rozdział Die bildrethorischen Strategien der Schönen Madonnen, s. 254-258.

54 Mayer wyróżniał trzy sposoby religijnego „patrzenia”: mistyczne (wewnętrzne, duchowe, wyrażające się w ekstazie i objawieniu), misteryjne (mistyk widzi cielesnymi oczyma symboliczną rzeczywistość, która jest wynikiem przeżycia świętych wydarzeń, actio) oraz zmysłowe (najprostsze, wręcz prymitywne zatopienie się w oglądaniu świętego przedmiotu). A. L. Mayer, Die heilbringende Schau in Sitte und Kult, w: Beiträge zur Geschichte des Alten Mönchtums und des Benediktinerordens, Hg. Ildefons Herwegen, Münster 1938, s. 234-262, zwł. s. 235-236. Proponowane przez Marcinkowskiego pośrednictwo Pięknych Madonn w komunii św. duchowej musiałoby się wiązać z kontemplacją wzrokową (Augenkommunion). 
ści musiał zaś sprzyjać wzrokowej kontemplacji i dialogowi z obrazem. Najdobitniej poświadcza to chyba niezwykła figura Madonny ze Sternberka, skłaniająca do modlitewnego compassio - zapatrzona w odległą wizję Męki Syna, trwożliwie osłaniająca Dzieciątko (jakby przed natarczywością spojrzeń), eksponuje zarazem stopę Chrystusa, już gotową na przyjęcie rany ${ }^{55}$.

Pod tym względem wspomniane figury stanowią zjawisko, w pobożności maryjnej na ziemiach Zakonu nowe (wpisują się zresztą w większą grupę dzieł o cechach i funkcjach dewocyjnych, które pojawiły się w miastach pruskich wraz ze stylem międzynarodowym ${ }^{56}$ ). Rodzi się pytanie, czy ich zaistnienie w Prusach było wynikiem samorzutnego rozprzestrzeniania się pewnych postaw religijnych i służących im wzorców artystycznych, czy świadomej działalności fundacyjnej w konkretnych uwarunkowaniach regionalnych? Próbowano tę kwestię rozstrzygnąć w dwojaki sposób, przy czym ogniskową odmiennych interpretacji była Piękna Madonna Toruńska. Spoglądano na nią albo jako na wynik działalności Krzyżaków, łącząc jej proweniencję z zamkiem krzyżackim w Toruniu (co Mojmir Frinta i Wolfgang Braunfels rozszerzyli na krąg Pięknych Madonn w ogóle ${ }^{57}$ ), albo - jako na wy-

55 R. Suckale, Die Sternberger Schöne Madonna, w: idem, Stil und Funktion. Ausgewählte Schriften zur Kunst des Mittelalters (Hg. P. Schmidt, G. Wedekind), München-Berlin 2003, 87-101, zwł. s. 92. Zob. także: J. Fajt, R. Suckale, Die Sternberger Schöne Madonna, w: Karl IV. Kaiser, s. 549 (nr 197).

56 Nie znaczy to, że w sztuce państwa zakonnego nie funkcjonowały wcześniej przedstawienia rzeźbiarskie, służące indywidualnej dewocji - jak np. krucyfiks z ołtarza św. Krzyża w kościele św. Jana w Toruniu czy Pietà z Ostródy. Przedstawienia te służyły jednak kontemplacji pasyjnej, wpisującej się w kult Męki Pańskiej, a nie - w cześć maryjną.

57 Teoria ta wiązała się początkowo z próbami ustalenia proweniencji figury Madonny toruńskiej - jako pierwszy jej pochodzenie z toruńskiego zamku konwentualnego zaproponował B. Schmid, Baukunst und bildende Kunst der Ordenszeit in Preussen, w: Deutsche Staatenbildung und deutsche Kultur im Preußenlande, Königsberg 1931, s. 116-150, zwł. s. 146. Za nim K. H. Clasen, Die mittelalterliche Bildhauerkunst, s. 133. Myśl tę rozwinięto w latach późniejszych, zob. zwł. M. Frinta, A portrait bust by the Master of Beautiful Madonnas, "The Art Quaterly”, Spring 1960, s. 36-50, zwł. s. 41-42. Jego zdaniem najważniejsze figury z tego kręgu powstały dla konwentów krzyżackich (Toruń, Wrocław, Krumłowo, Pilzno, Bonn), a białe płaszcze Madonn to aluzja do płaszczy rycerzy Zakonu. Podobny pogląd wyraził Braunfels, łącząc idealizm Pięknych Madonn z psychologią młodych rycerzy krzyżackich. W. Braunfels, Die 
raz dojrzewającej świadomości mieszczańskiej ${ }^{58}$. Pojawiły się również propozycje powiązania zarówno Madonny toruńskiej, jak i gdańskiej z konwentami franciszkanów, jednak mało przekonujące, bo oparte wyłącznie na analizie ikonografii towarzyszących rzeźbom nastaw ${ }^{59}$.

Wydaje się, iż teza o krzyżackiej genezie Pięknych Madonn traci na nośności, choć echa tych poglądów powracają nawet w aktualnych badaniach ${ }^{60}$. Arystokratyzm tych przedstawień mógł wprawdzie wpisywać się w zlaicyzowaną kulturę Zakonu na przełomie XIV i XV wieku, jednak - co wykazał Schwarz - Piękne Madonny, mimo "dworskiego” charakteru, nie bywały wynikiem dworskich patronatów, trójwymiarowe ujęcie obiektu kultowego tkwiło bowiem w mentalności ludowej ${ }^{61}$. Trudno też uznać nową koncepcję obrazową tych przedstawień za pendant dla Idealität des Rittertums von sehr jungen Männern ${ }^{62}$ i umieścić ich dewocyjny kontekst w kręgu potrzeb duchowości krzyżackiej,

Kunst im Heiligen Römischen Reich Deutscher Nation, Bd. 5: Grenzstaaten im Osten und Norden. Deutsche und slawische Kultur, unter Mitarbeit von Irena Kessler-Wetzig und Norbert Wolf, München 1985, s. 132.

58 M. Dygo, O kulcie maryjnym w Prusach Krzyżackich w XIV i XV w., s. 24.

59 Zdaniem Kruszelnickiej, treści ołtarza Pięknej Madonny Toruńskiej wiązały się z ideą Niepokalanego Poczęcia NMP, co było dla niej dowodem wykonania go w orbicie myśli franciszkańskiej. Ponieważ o ołtarzu Madonny nie wspominają wcześniejsze inwentarze kościoła św. Jana, miejscem pierwotnej ekspozycji retabulum Pięknej Madonny mogło być wobec tego lektorium kościoła franciszkańskiego. Badaczka stwierdziła wprawdzie, iż rzeźba mogłaby zostać pominięta przez wizytatorów fary, gdyby stanowiła wizerunek autonomiczny, ale taką możliwość z góry wykluczyła. J. Kruszelnicka, Dawny ołtarz Pięknej Madonny Toruńskiej, s. 67-68. Wniosek o franciszkańskiej proweniencji nie wydaje się już tak oczywisty, jeśli zakwestionuje się integralność ołtarza - sama Piękna Madonna na konsoli z Mojżeszem nie głosiła bowiem aż tak dobitnie idei Niepokalanego Poczęcia. Z kolei odnośnie do Pięknej Madonny Gdańskiej K. Zalewska sugerowała franciszkańską proweniencję, badając treści ikonograficzne różańcowego retabulum, por. przypis 47.

60 Z działalnością artystyczną Zakonu związał je ostatnio J. Fajt, Der Marienburger Ölberg-Christus, w: Karl IV. Kaiser, s. 417 (nr 13).

61 Jego zdaniem dzieła te podążały za kosmopolityczną estetyką, preferowaną w kręgu dworskich elit, ale ich fundatorzy z nich się nie wywodzili, tkwiąc w sferze wyobrażeń kultowych, posługujących się formą plastyczną. Choć więc mistrz Pięknej Madonny Toruńskiej mógł kształcić się w środowisku dworskim, trudno wyobrazić sobie króla czeskiego lub wielkiego mistrza Zakonu w roli fundatora takiej rzeźby. M. V. Schwarz, Schöne Madonna als komplexe Bildform, s. 94.

62 Cyt. za: W. Braunfels, Die Kunst im Heiligen, s. 132. 
realizujących się w obrębie zamkniętych kościołów konwentualnych ${ }^{63}$. Z zachowanych wzmianek o wyposażeniu kaplic zamkowych wynika wprawdzie, że kult maryjny miał w nich charakter dominujący i że istniały tam otaczane czcią przedstawienia NMP, najczęściej rzeźbiarskie, powiązane $\mathrm{z}$ ołtarzami o Mariackim patrocinium ${ }^{64}$. Z wieloma $\mathrm{z}$ nich związane były jednak ceremonialne przejawy czci - jak nakładanie metalowych koron ${ }^{65}$ czy przystrajanie szatami ${ }^{66}$. Niekiedy w inwentarzach mowa jest o niewielkich rozmiarach ${ }^{67}$ i ekskluzywnym materiale (srebro, kość słoniowa, bursztyn) ${ }^{68}$ maryjnych wyobrażeń. Choć więc w kaplicy komturstwa toruńskiego odnotowano w 1414 roku kultowe przedstawienie Matki Bożej, to fakt zaopatrzenia go w srebrną koronę i berło (wykorzystywane podczas uroczystości) ${ }^{69}$ wyklucza sugerowane dawniej pochodzenie Pięknej Madonny Toruńskiej z tamtejszego konwentu.

Wszystkie trzy Piękne Madonny pruskie zaistniały więc raczej nie w zamkniętych konwentach, ale w przestrzeniach sakralnych o publicznej

63 O kolektywnej naturze z gruntu tradycyjnych praktyk religijnych Krzyżaków zob. przede wszystkim: S. Kwiatkowski, Zakon Niemiecki w Prusach a umysłowość średniowieczna. Scholastyczne rozumienie prawa natury a etyczna i religijna świadomość Krzyżaków do ok. 1420 r., Toruń 1998, s. 93.

64 Za rzeźbione statuy Madonn z Dzieciątkiem uważa wymieniane w krzyżackich źródłach „bilde unseren lieben frouwen”. W. Rozynkowski, Der Marienkult in den Kapellen der Deutschordenshäuser in Preußen im Lichte der Inventarbüchern, w: Terra Sanctae Mariae, s. 57-67.

65 Bałga (w 1427 r. wymieniona srebrna korona), Brodnica (inwentarz wymienia wyobrażenie Marii oraz dwie korony wiszące na ołtarzu), Elbląg (srebrnymi koronami ozdobiono głowy Marii i Dzieciątka), Królewiec (inwentarz z 1431 r. wymienia cztery srebrne korony), Labiawa (3 srebrne korony), Malbork (inwentarz z $1394 \mathrm{r}$. podaje dwie korony ze srebra i dwie „von fyenem golde”, z 1437 r. - wspomina też o złotej i srebrnej koronie Dzieciątka), Ragneta (w 1425 r. odnotowane srebrne korony dla Marii i Dzieciątka). W. Rozynkowski, Omnes Sancti, s. 158-167.

66 Rozynkowski interpretuje w tym kontekście zapis o kilku „mentel unser lieben frouwe" w inwentarzu kaplicy w Grudziądzu. Ibidem, s. 161.

67 Brodnica: „eyn klein unser frauwen bilde”; Kowalewo: „2 bildechin unszer frawen”. Ibidem, s. 159, 161.

68 W Grudziądzu w 1434 r. zapisano „1 bilde unser lieben frauwen von helfenbeyn”; w Szczytnie w 1440 r. - „unsir frauwen bilde silbern” oraz „bilde van bornsteyn”; w Kowalewie - „beynen”. W. Rozynkowski, Der Marienkult, s. 58-59.

69 Ibidem, s. 61. 
dostępności i funkcjonowały w służbie pobożności dwóch największych pruskich metropolii. W charakterystyce kultu maryjnego w Prusach, przedstawionej przez Mariana Dygo miało to wyjątkowe, symboliczne znaczenie. Piękna Madonna Toruńska, stworzona dla środowiska mieszczańskiego, przeciwstawiła bowiem ludzki wymiar macierzyńskiego szczęścia obrazowi władczej i wojującej protektorki Krzyżaków ${ }^{70}$. Byłby to dowód „rywalizacji o patronkę” pomiędzy Zakonem a mieszczaństwem $^{71}$, jaką Dygo uznał za jedną z płaszczyzn społeczno-politycznego konfliktu w państwie krzyżackim na przełomie XIV i XV wieku. Takie „modelowe” przeciwstawienie ideału Pięknych Madonn Zakonowi (rozumianemu jako władca terytorialny) budzi jednak pewne zastrzeżenia. Choć rzeczywiście konflikt pomiędzy miastami a Zakonem narastał już od końca XIV wieku, dopiero czas po klęsce grunwaldzkiej przyniósł świadome działania rad na rzecz organizacji życia religijnego ${ }^{72}$ - dopiero wówczas można byłoby więc uznać Piękną Madonnę za jakiś rodzaj wizualnej manifestacji, od czego zresztą sam Marian Dygo był daleki. Co więcej, w dotychczasowych badaniach sygnalizowano już, iż figury te, z ich „materialną niematerialnością”, mogły być świadomą kreacją Kościoła instytucjonalnego - to przecież on sankcjonował istnienie tych przedstawień w przestrzeni liturgicznej ${ }^{73}$. Być może, w obliczu kryzysu autorytetu Kościoła, jaki nastąpił pod koniec XIV wieku, chodziło o nową wizualizację „substancji” kultowej, cielesności ukrytej pod płaszczem abstrakcyjnych pofałdowań draperii. Pytanie, na ile sami mieszczanie mogli ku takiej treści dążyć, na ile byli jej świadomi? Czy za fundacją Pięknej Madonny Toruńskiej - podobnie jak za gdańską figurą Bractwa Kapłańskiego NMP - nie stało raczej duchowieństwo? A przecież w końcu XIV wieku kler parafialny nadal prezentowany był przez Zakon, który wpływał na pracę duszpasterską plebanów ${ }^{74}$.

Pytanie o genezę Pięknych Madonn na gruncie państwa zakonnego nie jest więc łatwe i nie przynosi jednoznacznej odpowiedzi, jako że

70 M. Dygo, O kulcie maryjnym w Prusach Krzyżackich w XIV i XV w., s. 24.

71 Ibidem, s. 36.

72 R. Czaja, Miasta pruskie a zakon krzyżacki. Studia nad stosunkami między miastem a władza terytorialna w późnym średniowieczu, Toruń 1999, s. 222-223.

73 H. Beck, H. Bredekamp, Der internationale Stil, s. 70.

74 R. Czaja, Miasta pruskie a zakon krzyżacki, s. 46-52. 
wpisuje się w inny, nierozstrzygnięty spór - o rzeczywistą inicjatywę, rolę intelektualną i wkład materialny Krzyżaków w sztukę powstającą w miastach pruskich ${ }^{75}$. Do istniejących hipotez na temat kontekstu społecznego i funkcji Pięknej Madonny Toruńskiej dodajmy zatem jeszcze jedną - może najbardziej neutralną. Rzeźba ta zaistniała w służbie pobożności miejskiej a kwestii jej fundacji nie rozstrzygniemy bez archiwalnych przekazów. Jej oryginalna forma ani nie wyrastała z krzyżackiej estetyki, ani nie wiązała się z krzyżacką inicjatywą, ale też się z nią celowo nie kłóciła, co więcej - jej przekaz mógł być nawet Krzyżakom pomocny. Na ogólnoeuropejski spadek zaufania do Kościoła nałożył się wszak w państwie krzyżackim upadek autorytetu Zakonu w przededniu wojny z Polską. Jeśli - jak chciał Belting - piękno Pięknych Madonn to wyidealizowany obraz Kościoła ${ }^{76}$, trudno o jego dobitniejszą apologię niż Madonna toruńska, jedyna zachowana z rzeźbioną konsolą, jedyna stojąca na fundamencie Starego Prawa. Poza tym, jakkolwiek nie spojrzeć na „regionalny” problem fundacji Pięknych Madonn pruskich, ich fenomen trudno oceniać jako wynik lokalnej ewolucji światopoglądu i praktyki religijnej. Ich fundatorzy musieli być czuli na nowe rozwiązania artystyczne, ale trudno orzec, na ile mogli mieć wpływ na wizualizację konkretnych idei - źródła typu wszystkich trzech omawianych figur biły bowiem poza państwem zakonnym.

\section{Problemy stylu i atrybucji}

Po okresie licznych polemik - zwłaszcza w kontekście pracy Clasena ${ }^{77}$ - przyjmuje się na ogół, iż Piękne Madonny wyrosły z doświadczeń sztuki czeskiej. Przykładowo, niewielka drewniana figura Madonny z Horaždovic, reprezentująca zasadniczo typ „toruński”, tchnie także znajomością innych motywów typologicznych (Krumłowo, Altenmarkt)

75 Zob. na ten temat np. M. Arszyński, Stosunki między zakonem krzyżackim a społeczeństwem w świetle rozważań nad organizacją budowy kościołów parafialnych w Prusach, w: Zakon krzyżacki a społeczeństwo państwa w Prusach, red. Z. H. Nowak, Toruń 1995, s. 165-184.

76 H. Belting, Image et culte, s. 589.

77 Zob. przyp. 10. 
oraz malarstwa czeskiego ${ }^{78}$, musiała więc powstać u źródła wszystkich tych koncepcji. Niezależnie od tez Clasena, wielokrotnie w dotychczasowych badaniach podkreślano więc praskie źródła stylu Pięknej Madonny Toruńskiej. Istotnym przyczynkiem do tego rozpoznania były ustalenia Alberta Kutala o wzajemnym związku i tożsamym autorstwie rzeźby ze Sternberka ${ }^{79}$, która najpewniej powstała w Pradze. Na bliskie powinowactwo obu dzieł wskazał też - choć nieco ostrożniej - Gerhardt Schmidtt ${ }^{80}$, który zaliczył je (włączając tu także Madonnę wrocławską), do wspólnej grupy typologiczno-warsztatowej, inspirowanej stylem Parlerów. Parlerowskie korzenie formy Pięknej Madonny Toruńskiej bywały zresztą podkreślane jeszcze dobitniej - Jaromir Homolka w opublikowanym stosunkowo niedawno artykule chciał widzieć w niej (chyba jednak niesłusznie!) dzieło samego Piotra Parlera ${ }^{81}$. Również konsola z Mojżeszem uważana jest zwykle za rozwinięcie stylu figur z nagrobków Przemyślidów w katedrze św. Wita ${ }^{82}$. W dotychczasowych badaniach zaskakującą obecność rzeźby o kluczowym znaczeniu dla rozpoznania całego kręgu Pięknych Madonn na odległych krzyżackich terytoriach tłumaczono wykonaniem jej in situ przez mi-

78 J. Fajt, Virgin and Child, w: Prague. The Crown of Bohemia 1347-1447, s. 265 (nr 113): Praga, 1380; idem, Madonna aus Horaždovice, w: Karl IV. Kaiser, s. 549-550 (nr 198): Praga, 1390 (?).

79 A. Kutal, Madona ve Šternberku a její Mistr, „Umění” 1958, t. VI, s. 111-150, zwł. s. 116.

80 G. Schmidt, Paralipomena zu der Ausstellung „Die Parler und der Schöne Stil”, w: idem, Gotische Bildwerke und ihre Meister, Wien-Köln-Weimar 1992, s. 269-312., zwł. s. 291.

81 J. Homolka, Paris - Gmünd - Prag. Die königliche Allerheiligenkapelle auf der Prager Burg, w: Parlerbauten. Architektur, Skulptur, Restaurierung. Internationales Parler-Symposium, Schwäbisch Gmünd, (Landesdenkmalamt Baden-Württemberg. Arbeitsheft 13), Hg. R. Strobel, A. Siefert, K. J. Hermann, Stuttgart 2004, s. 135-140, zwł. s. 136.

82 A. Kutal, Madonna ve Sternberku, s. 116; G. Schmidt, Peter Parler und Heinrich IV. Parler als Bildhauer, w: idem, Gotische Bildwerke, s. 108-228, zwł. s. 207. Zwracano przede wszystkim uwagę na powinowactwo ekspresji twarzy Mojżesza i wizerunków książęcych z nagrobków Przemyślidów w katedrze św. Wita w Pradze. Kutal przyjął na tej podstawie, że twórca konsoli z Mojżeszem kształcony był w obrębie strzechy Parlerów w Pradze. 
strza, przybyłego z Pragi ${ }^{83}$. Założenie to zostało oparte na analizie zachowanego w Prusach oeuvre mistrza, które ustalił jeszcze Karl Heinz Clasen $^{84}$, a także na przekonaniu, że styl warsztatu Pięknej Madonny na długo wpisał się w twórczość Ordenslandu. Obydwa te poglądy wymagają jednak weryfikacji.

Nie wiadomo, skąd pochodzi (a więc czy w Prusach powstała) siostrzana figura toruńskiej Pięknej Madonny, przechowywana w Rheinisches Landesmuseum w Bonn i wiązana z jej warsztatem; w najnowszych badaniach definitywne ustalenie miejsca jej wykonania rodzi pewne trudności ${ }^{85}$. Za czeskie importy można uznać dwa inne dzieła toruńskie z domniemanego dorobku mistrza, przy czym Maria brzemienna mogła być dziełem pracowni o zupełnie innej formacji niż Piękna Madonna ${ }^{86}$. Z kolei figura Chrystusa Ogrójcowego w Malborku - nawet jeśli faktycznie jest dziełem tego samego mistrza - wykonana została z opoki praskiej ${ }^{87}$, jak wiele czeskich dzieł stylu międzynarodowego, co sankcjonuje przekonanie o jej imporcie.

83 K. H. Clasen, Die mittelalterliche Bildhauerkunst, s. 132; G. Schmidt, [rec. Clasen], s. 71; J. Fajt, Der Marienburger Ölberg-Christus; J. Chapuis, Bonner Madonna, w: Karl IV. Kaiser, s. 449-450 (nr 144), Labuda Adam S., Das Meer im Blick-Expansion nach Norden, w: Karl IV. Kaiser, s. 401-415, zwł. s. 405-406.

84 K. H. Clasen, Die mittelalterliche Bildhauerkunst, s. 132-191; idem, Der Meister, s. 33-45, 100-105. Clasen zaliczył do własnoręcznych dzieł mistrza figurkę Marii Brzemiennej, która do II wojny światowej znajdowała się w Muzeum Miejskim w Toruniu, a zgodnie z relacją Clasena znaleziona została w Papowie Biskupim oraz rzeźbę Chrystusa Ogrójcowego z Malborka, pochodzącą być może z kościoła św. Jana w Toruniu. Mimo wielu kontrowersji wobec głównych tez Clasena, spójność tego dorobku została uznana nawet przez Alberta Kutala; idem, Ein neues Buch, s. 546.

85 Por. przykładowo atrybucje tego samego autora: J. Chapuis, Bonner Madonna, s. 449: „Toruń (?), mistrz Madonny toruńskiej i warsztat, ok. 1395”; idem, Virgin and Child, w: Prague. The Crown of Bohemia 1347-1447, s. 254-255 (nr 107): „Czechy, ok. 1395”.

86 A. Jagodzińska, Maria Dobrej Nadziei - styl i ikonografia rzeźby z terenu państwa zakonnego w Prusach, w: „Teka Komisji Historii Sztuki” 2005, t. X, s. 86-95, zwł. s. 92. Autorka wskazała na elegancję formy figury, płynącą z warsztatów wiedeńskich; analiza konsoli zaś doprowadziła ją do wniosku o praskiej proweniencji dzieła.

87 J. Fajt, Der Marienburger Ölberg-Christus, s. 417. Użycie opoki (Pläner Kalkstein) traktowane jest częstokroć jako dowód na praską proweniencję, jak w przypadku Madonn z Pilzna i Altenmarkt czy figury św. Elżbiety z Thann koło Grosslobming. 
Tymczasem założenie o wspólnym autorstwie Madonny i Chrystusa oraz działalności mistrza w Toruniu zawiodło w najnowszych badaniach ku dość skomplikowanej konkluzji: Chrystus Ogrójcowy miałby być krzyżackim importem z Pragi do Malborka ${ }^{88}$, Piękna Madonna zaś - dziełem tego samego mistrza, którego sprowadzono później do Torunia $^{89}$. Za jego własnoręczną pracę uznano też ostatnio rzeźbę Marii Magdaleny w kościele św. Jana w Toruniu ${ }^{90}$ (il. 4), jeden z nielicznych na ziemi chełmińskiej przykładów tak samodzielnego rozwinięcia form stylu międzynarodowego ${ }^{91}$. Kompozycja ta - wbrew opinii Fajta - nie znajduje jednak bliższych analogii w kręgu czeskim, jej styl wiedzie raczej ku Europie Zachodniej ${ }^{92}$. Bardziej przekonująca wydaje się więc

88 Ibidem. Fajt pominął, Labuda zaś odrzucił teorię Dobrego o toruńskim przeznaczeniu figury Chrystusa. A. Labuda, Das Meer im Blick, s. 406, przyp. 26; A. Dobry, Rzeźba Chrystusa w Ogrójcu ze zbiorów Muzeum Zamkowego w Malborku, „Nasza Przeszłość” 1993, t. LXXX, s. 107-130.

89 J. Fajt, Der Marienburger Ölberg-Christus, s. 418.

90 Fajt i Chapuis uważają figurę za dzieło mistrza Pięknej Madonny; por. J. Fajt, Der Marienburger Ölberg-Christus; J. Chapuis, Bonner Madonna. Do kręgu Mistrza Pięknej Madonny Toruńskiej włączył ją już Clasen, który niesłusznie przypisał ją Mistrzowi Ukrzyżowania z Chełmży - równie niesłusznie łącząc tego mistrza z twórcą toruńskiej Madonny. K. H. Clasen, Die mittelalterliche Bildhauerkunst, s. 180. Ani zestawienie reliefu Marii Magdaleny z chełmżyńskim Ukrzyżowaniem, ani łączenie samego Ukrzyżowania z Mistrzem Pięknej Madonny, nie wytrzymują krytyki. Liryczne ujęcie figur asysty stoi w wyraźnej opozycji wobec surowej, plebejskiej w wyrazie figury Chrystusa o zupełnie innych proporcjach, co mogłoby podawać w wątpliwość nawet jednorodność chełmżyńskiej grupy. Sposób upozowania, rzut draperii szat i typ fizjonomii zbliżają natomiast rzeźby Marii i Jana do dzieł ostatniej fazy czeskiego stylu międzynarodowego (bliskie np. Ukrzyżowaniu Dumlosych, łączonemu z Mistrzem Tyńskiej Kalwarii).

91 Przeprowadzona w 1998 r. konserwacja dzieła ujawniła jego niewątpliwą przynależność do stylu pięknego, wbrew wcześniejszym twierdzeniom, które łączyły ją niekiedy z późnym gotykiem. Gwido Chmarzyński np. datował na 1500 r.; G. Chmarzyński, Sztuka w Toruniu. Zarys dziejów, w: Dzieje Torunia, red. K. Tymieniecki, Toruń 1933, s. 471-544, zwł. s. 506.

92 Zamiłowanie do wielofiguralnych grup ołtarzowych o przemyślanym systemie kompozycyjnym i dużej autonomii plastycznej a także dbałość o drobiazgowe wykończenie szczegółów (jak bujne loki o dynamicznych układach i graficznym modelunku), znajdujemy raczej w sztuce zachodniej - przykładowo w rzeźbie Środkowej Nadrenii z lat 1415-1440, jak np. terakotowa kompozycja z ołtarza Niesienia Krzyża z Lorch, ok. 1425 r. (w berlińskiej Skulpturensammlung SMPK) czy pochodzący z tego samego kręgu warsztatowego ołtarz Zaśnięcia Marii w kościele św. Jana w Kronberg 
niedawna propozycja Labudy, iż jest ona dziełem mistrza, który podjął modus estetyczny Pięknej Madonny ${ }^{93}$, przy czym nie można się oprzeć wrażeniu, że twórca ten - również lokalnie wyobcowany - świadom był rozwiązań, zapowiadających już sztukę Hansa Multschera. Wszystko to skłania według mnie do przypuszczenia, że Madonna wraz ze swą konsolą nie tylko wywodzi się z tradycji czeskiej, ale - podobnie jak Chrystus Ogrójcowy i Maria Brzemienna - miała swe miejsce pośród aktualnych dokonań tamtejszych pracowni.

Kwestia oddziaływania domniemanych dzieł „Mistrza toruńskiej Madonny" na miejscowe środowisko jest dla badań nad sztuką Prus około 1400 roku dużo istotniejsza, niż trudny do jednoznacznego rozwiązania problem jego osobistej obecności w Prusach. Konsekwencją założenia o lokalnej działalności warsztatu mistrza, „przynoszącego mu wielką sławę przez ponad dwadzieścia lat" ${ }^{\prime 4}$, jest pogląd o prężnym oddziaływaniu tego twórcy na ewolucję lokalnego środowiska. Niezależnie jednak od tego, czy takowy mistrz przebywał na ziemiach Zakonu, czy też dzieła (różnych?) praskich pracowni trafiały tu na zasadzie importu, rzeczywista recepcja tej fazy stylu pięknego jest w Prusach - przy obecnym stanie zachowania - niełatwa do uchwycenia. Odrywając się od Clasenowskiego teorematu działających tu „uczniów mistrza”, trudno jest zaproponować spójną systematykę zachowanych dzieł z pierwszej połowy XV wieku - większość atrybucji rozmaitym „kręgom warsztatowym" zachowuje charakter raczej hipotetyczny. Niska jakość dużej czę-

nad Taunusem, ok. 1440 r., z wyłaniającymi się ze stylizowanych obłoków, dynamicznymi figurami aniołów. Na zachodnią (przypuszczalnie frankońską) genezę rzeźby wskazywała też E. Pilecka, Kościół p.w. św. Jana Chrzciciela i Jana Ewangelisty w Toruniu w okresie średniowiecza jako wizualizacja świadomości społecznej, w: Dzieje i skarby kościoła świętojańskiego w Toruniu, red. K. Kluczwajd i M. Woźniak, Toruń 2002, s. 119-176, zwł. s. 160; nadreńskie korzenie sugerują ostatnio: A. Błażejewska, E. Pilecka, Sztuka średniowieczna, w: Dzieje sztuki Torunia, Toruń 2009, s. 15-153, zwł. s. 101.

93 A. Labuda, Das Meer im Blick, s. 408-409.

94 J. Fajt, Der Marienburger Ölberg-Christus, s. 418: „und dort eine Werkstatt gründete, die ihm mehr als zwanzig Jahre lang großen Ruhm einbrachte”. Pogląd o prężnym oddziaływaniu tego mistrza na ewolucję lokalnego środowiska przyjmuje także A. Labuda, Das Meer im Blick, s. 408: „z całą pewnością mistrz przyczynił się do rozprzestrzenienia się stylu pięknego w Prusach około i po 1400 roku". 
ści lokalnej produkcji snycerskiej prowadzi do wniosku, że to pojedyncze rzeźby pochodzące z importu, nie zaś prężna działalność napływowych warsztatów, warunkowały popularność niektórych rozwiązań stylu pięknego, przynajmniej do lat dwudziestych XV wieku - choć należy podkreślić, że założenie to ma charakter pewnego uogólnienia. Następstwo form, oparte na recepcji modelu, można moim zdaniem wychwycić na gruncie rzeźby z domeny gdańskiej, gdzie niektóre dzieła czeskie mogły służyć jako wzorce typologiczne dla lokalnych naśladownictw ${ }^{95}$.

Podobne zjawisko, ale na dużo mniejszą skalę, dotyczy także dzieł, łączonych z Piękną Madonną Toruńską. Trudno zawyrokować, czy w pruskim środowisku powstała jedyna dobrej klasy transpozycja jej typu na drewno, wtórnie wkomponowana w ołtarz rodziny Junge w kościele św. Mikołaja w Stralsundzie, pierwotnie zaś - pełnoplastyczna i samodzielna ${ }^{96}$. Jej proweniencja była jak dotąd oceniana rozmaicie - widziano w niej dzieło nadreńskie ${ }^{97}$, północne (lubeckie) ${ }^{98}$, tudzież pochodzące z państwa zakonnego (Gdańska ${ }^{99}$ lub Torunia ${ }^{100}$ ). Burkhart Kunkel zasugerował wykonanie jej w warsztacie kamieniarskim przez

95 Na ten temat zob. szczegółowo: M. Jakubek-Raczkowska, Rzeźba gdańska przełomu XIV i XV wieku, s. 115-132.

96 Na ten temat ostatnio: B. Kunkel, Die Stralsunder Junge-Madonna als EbenBild der Schönen Madonna von Thorn. Überlegungen zur Herkunft und ihrer Beziehung aus Stralsunder Perspekitive, w: Terra Sanctae Mariae, s. 257-277.

97 E. Fründt, Der Junge Altar aus der St. Nikolaikirche zu Stralsund. Ein Beitrag zum Problem der Werkstoffverwendug in der mittelalterlichen Plastik, w: Staatliche Museen zu Berlin, hg., „Forschungen und Berichte” 1962, H. 5, s. 25-30, zwł. s. 28.

98 Podkreślano „północny” charakter fizjonomii Madonny jako efekt hanzeatyckiej transformacji dworskiego ideału. H. Wenzel widział w tej rzeźbie „eine schöne Madonna in Niederdeutschland formuliert”, Dzieciątko uznał za lubeckie („plattdeutsch”, „übisch”); idem, Niederdeutsche Madonnen, Hamburg 1941, s. 24-25. Także Nikolaus i Rosemarie Zaske wskazali na „herbe, fast mürrische Gesicht” Madonny; N. i R. Zaske, Kunst in Hansestädten, Leipzig 1985, s. 169.

99 Tu podstawą określenia było zastosowanie drewna orzechowego. Zdaniem Tångeberga, figura powstała w Gdańsku, ale wyszła spod ręki mistrza, przybyłego z północy, który zetknął się tu z nową estetyką: P. Tångeberg, Das „Schöne Kruzifix” in Vadstena und Nussbaumholzskupturen aus dem Deutschordensland, (Antikvarisk Arkiv 75), Stockholm 1993, s. 43-44.

100 Zdaniem Vossa, mogła być ona dziełem mistrza kształconego w Toruniu, który osiadł na północy. J. Voss Johannes, Die Stralsunder Junge-Madonna. Ein Beitrag zur Entstehung des Retabels und zur Werkstoffgeschichte in Nordostdeutschland im 15. 
mistrza, znającego modele toruński i wrocławski ${ }^{101}$. Istnienie tej transpozycji nie rozstrzyga jednak ani o miejscu wykonania samej Madonny toruńskiej, ani o powstaniu dzieła stralsundzkiego w bezpośredniej orbicie wykonawcy pierwowzoru. Figura stralsundzka może pochodzić zarówno z Pragi ${ }^{102}$, jak i z Ordenslandu, w tym drugim przypadku byłaby jednak wyjątkowym przykładem tak doskonałej recepcji. Jedynym znanym mi snycerskim naśladownictwem Pięknej Madonny Toruńskiej na ziemi chełmińskiej jest rzeźba z kościoła parafialnego w Chwaszczynie ${ }^{103}$, w której próbowano bez zrozumienia dla pryncypiów stylowych odtworzyć nie tylko ogólną relację postaci, ale i układ pofałdowań. Transpozycje na miarę Madonny ze Stralsundu albo na tych ziemiach nie istniały, albo nie przetrwały do naszych czasów.

Nieliczne przykłady typologicznej recepcji wiążą się także z malborskim Chrystusem Ogrójcowym, którego dewocyjne ujęcie musiało trafnie wpisać się w potrzeby duchowe gmin pruskich ${ }^{104}$. Nawet w przypadku dobrej klasy figury z kościoła św. Jakuba w Toruniu trudno się jednak zgodzić z Clasenem, iż jest ona dziełem ucznia Mistrza Madonny Toruńskiej. Manieryczna stylizacja opracowania powierzchni rzeźbiarskiej i uproszczenie proporcji czynią z niej raczej dzieło naśladowcze

Jh., w: Entstehung und Frühgeschichte des Flügelaltarschreins, Hg. H. Krohm, K. Krüger, M. Weniger, Berlin 2001, 69-72.

101 B. Kunkel, Die Stralsunder Junge-Madonna, s. 274.

102 Charakterystyczny ideał jej urody nie jest jeszcze wystarczającym argumentem za jej nadbałtycką genealogią. Takie cechy, jak charakterystycznie uformowany nos, szeroko rozstawione oczy o lancetowatym kroju, podkreślenie bruzdy okołonosowej, cofnięty podbródek, znajdują swe analogie w czeskim popiersiu Madonny ze zbiorów nowojorskiego Metropolitan Museum of Art, datowanym na lata 1390-1395 i stylistycznie wiązanym również z kręgiem Pięknej Madonny toruńskiej. Por. J. Chapuis, Tonbüste einer gekrönten Jungfrau, w: Karl IV. Kaiser, s. 519-520, (nr 181). Kunkel, nie rostrzygając kwestii proweniencji stralsundzkiej Madonny, wskazuje istnienie szlaku handlowego, biegnącego z Czech przez Stralsund do Lubeki. B. Kunkel, Die Stralsunder Junge-Madonna, s. 274.

103 Dzieło zaginione, reprod. w: K. H. Clasen, Die mittelalterliche Bildhauerkunst, Bd. 2, il. 209.

104 Chrystus Ogrójcowy z kościoła św. Jakuba w Toruniu, obecnie w Muzeum Diecezjalnym w Pelplinie. Zaginiony w 1945 r. Chrystus Ogrójcowy z kościoła parafialnego w Lidzbarku Warmińskim, publikowany w: K. H. Clasen, Die mittelalterliche Bildhauerkunst, Bd. 2, il. 319. 
o niepewnej - być może nowożytnej - metryce ${ }^{105}$. Istnienie nawiązań typologicznych nie przesądza więc jeszcze o działalności kształconych w warsztacie Mistrza „kontynuatorów”.

W najnowszych badaniach do dzieł z kręgu naśladowców warsztatu Pięknej Madonny zaliczono Męża Boleści w kościele św. Jana w Toruniu ${ }^{106}$ (niewątpliwie dobrej klasy dzieło stylu międzynarodowego, pozbawione jednak wnikliwszego rozpoznania) oraz odmienną w koncepcji formalnej, nieco wcześniejszą figurę św. Barbary z Barbarki pod Toruniem ${ }^{107}$. Starsza literatura, od Clasena począwszy, opierała się natomiast na przekonaniu, że lokalnym odpryskiem działalności mistrza Pięknej Madonny Toruńskiej była twórczość jego ucznia i naśladowcy - Mistrza Pięknej Madonny z kościoła Mariackiego w Gdańsku. Tymczasem, mimo przynależności Madonny gdańskiej do „typu prusko-śląskiego” i mimo jej pozornej zależności od Madonny toruńskiej, jaka czytelna jest w kompozycji draperii, dzieła te w istocie więcej dzieli, niż łączy ${ }^{108}$. Figura gdańska jest kreacją samodzielną, która zresztą - podobnie jak i rzeźba toruńska - nie ma w państwie krzyżackim ani uchwytnej tradycji, ani zdecydowanej kontynuacji. Wyrosła ona z przesłanek stylowych, które na tych ziemiach były jeszcze bardziej obce, niżeli obecne tu od połowy XIV wieku wpływy czeskie. Zasadnicza różnica pomiędzy obydwoma dziełami tkwi nie w typie, stylu czy warsztacie, ale w odmiennym stosunku do tej samej, francuskiej tradycji.

W tym miejscu rozważania nad rzeźbami pruskimi wpisują się w dyskusję nad genezą kręgu Pięknych Madonn. O ile bowiem Clasenowska Ein-Meister-Theorie nie znalazła uznania znawców sztuki

105 Ostatnio także: A. Błażejewska, E. Pilecka, Sztuka gotycka, s. 141, il. 129 na s. 129: uznały rzeźbę za nowożytną i wydatowały ją na wiek XVII.

106 J. Fajt określa dzieło jako powstałe zumindest im Kontakt z mistrzem Pięknej Madonny; idem, Der Marienburger Ölberg-Christus, s. 418.

107 Ibidem. A. Labuda traktuje św. Barbarę oraz pokrewną jej figurę św. Elżbiety z Malborka za dzieła rozwijające styl Pięknej Madonny; idem, Das Meer im Blick, s. 408. Na temat ich czeskiej genezy formalnej oraz możliwości wcześniejszego datowania (na lata 1385-1390) inaczej: M. Jakubek-Raczkowska, Rzeźba gdańska przełomu XIV i XV wieku, s. 98-103.

108 Zob. analiza porównawcza w: M. Jakubek-Raczkowska, Rzeźba gdańska przełomu XIV i XV wieku, s. 79. O wyjątkowości stylistycznej Pięknej Madonny Gdańskiej na tle kręgu Pięknych Madonn: ibidem, s. 74-76. 
środkowoeuropejskiej ${ }^{109}$, o tyle idea zachodniego rodowodu stylu tego kręgu powracała jeszcze kilkakrotnie. Przełomową rolę w tym względzie odegrała publikacja Roberta Didier i Rolanda Rechta ${ }^{110}$, która otworzyła nową perspektywę dla badań nad sztuką europejską: w kontekście zaniedbanych podówczas przez naukę, a tak bujnych dokonań sztuki paryskiego dworu Karola V de Valois ${ }^{111}$. Uczeni zwrócili uwagę na fakt, iż paralelne zjawisko, jakim był typ Madonny paryskiej z drugiej połowy XIV wieku, znalazł swą recepcję także w gronie konserwatywnych dzieł, uznawanych za Piękne Madonny. Z drugiej strony sam krąg określili jako grupę inconstablement bohemienne, dla której Madonny paryskie stanowiły nie źródło, a ekwiwalent czy nawet antytezę ${ }^{112}$. Podobnym tropem podążyli też inni badacze ze środowiska francuskiego, choć problem sztuki około 1400 roku w kontekście międzynarodowym pozostaje raczej tematem w literaturze francuskiej wyobcowanym. Przy świadomości przemożnego wpływu tradycji paryskiej na kreację praską doby Luksemburgów, uznaje się na ogół Piękne Madonny za wytwór zdecydowanie środkowoeuropejski, zachowujący swoistą „słowiańską” odrębność, wobec której Madonny francuskie końca XIV wieku były jedynie alternatywą ${ }^{113}$.

Z drugiej jednak strony, kwestia genezy kręgu Pięknych Madonn zyskała też dużo śmielsze interpretacje. Michael Victor Schwarz ${ }^{114}$ za-

109 Por. przyp. 10.

110 R. Didier, R. Recht, Paris, Prague, Cologne.

111 Rozkwit artystyczny Paryża w tym okresie został naświetlony w latach 1981-1982 dzięki paryskiej ekspozycji „Les fastes du Gothique” w Galeries nationales du Grand Palais: Les fastes du Gothique. Le siècle de Charles V, red. F. Baron, Paris 1981.

112 R. Didier, R. Recht, Paris, Prague, Cologne, s. 195-197.

113 Np. S. Guillot de Suduiraut uważa Madonny paryskie za zjawisko wobec Pięknych Madonn paralelne, ale „odmiennie zinterpretowane” (interprété diversement); S. Guillot de Suduiraut, Le Flamboyant gothique (1400-1539), w: La sculpture. De l'antiquité au Moyen Age. Du VIII e siècle avant J.-C. au XVe siècle, red. G. Duby, X. Barral Y Altet, S. Guillot de Suiduiraut, Köln 2006, s. 471-540, zwł. s. 474-475. E. Antoine traktuje grupę rzeźb paryskich z lat około 1400 jako wewnętrznie niejednorodną i opartą na całkowicie odmiennych wyznacznikach formalnych niż Piękne Madonny; E. Antoine, Vierges à l'Enfant: des Belles Madones?, w: Paris 1400. Les arts sous Charles VI, (cat. d'exposition Louvre), red. E. Taburet-Delahaye, Paris 2004, s. 324-325.

114 M. V. Schwarz, Höfische Skulptur im 14. Jahrhundert. Entwicklungsphasen und Vermittlungswege im Vorfeld des Weichen Stils, Bd. 1-2, Worms 1986 (Manuskript 
proponował spojrzenie na całość zjawisk w sztuce XIV i początku XV wieku przez pryzmat kontaktów pomiędzy dworami europejskimi, ze szczególną rolą ośrodka w Budzie - styl Pięknych Madonn był według niego wynikiem działalności artystów francuskich ${ }^{115}$, którzy po ukończeniu prac na zlecenie Zygmunta Luksemburskiego rozproszyli się po Europie Środkowej ${ }^{116}$. Możliwość wędrówek artystów francuskich, wywołanych kryzysem ekonomicznym i społecznym, założyła także Ulrike Heinrichs-Schreiber we wnikliwym studium rzeźby paryskiej czasów Karola V i Karola VI ${ }^{117}$. Jej zdaniem, dokonania paryskie mogły mieć wpływ na warsztat Parlerów ${ }^{118}$, a współczesna sztuka francuska zainspirowała powstanie typu Pięknych Madonn w latach około 1380 roku $^{119}$. Podobne stanowisko zajęła Agnieszka Łaguna-Chevilotte, wskazując na francuskie korzenie wielu reprezentatywnych cech stylu Pięknych Madonn ${ }^{120}$. Mimo wspomnianych propozycji - przy braku źródeł pisa-

zur Kunstwissenschaft). Por. także recenzje: E. Marosi, „Acta Historiae Artium Academiae Scientiarum Hungaricae” 1989, nr 34, s. 61-64; W. Marcinkowski, „Folia Historiae Atrium” 1991, nr 27, s. 147-152. Krytycznie wobec „węgierskiej” propozycji Schwarza ustosunkował się także J. Kębłowski, Dwie antytezy w sprawie tzw. Pięknych Madonn, w: Sztuka ok. 1400. Materiały Sesji SHS, Poznań, listopad 1995, t. I, Warszawa 1996, s. 165-185, zwł. s. 174-175.

115 M. V. Schwarz, Höfische Skulptur, s. 469-495 [Die Meister der Schönen Madonnen - eine neue Hypothese].

116 Ibidem. Zdaniem Schwarza, w warsztatach budzińskich wykształceni zostali mistrzowie: Pięknej Madonny Toruńskiej (s. 469-477), Mistrz z Grosslobming (s. 477-79), Madonny z Krumłowa (s. 479-480), Madonny z Klostreneuburga oraz Męża Boleści w kościele św. Michała w Wiedniu (s. 480-483). Zwraca jednak uwagę późniejsza autopolemika Schwarza, por. M. V. Schwarz, Schöne Madonna, s. 95, przyp. 13.

117 U. Heinrichs-Schreiber, Die Bedeutung der französisch-höfischen Bildhauerkunst für den Meister aus Grosslobming, w: Der Meister von Grosslobming, Ausstellungskatalog, hg. Artur Saliger, Wien 1994, s. 9-29, zwł. s. 16-17; eadem, Vincennes und die höfische Skulptur. Die Bildhauerkunst in Paris 1360-1420, Berlin 1997, s. 228-229.

118 Ulrike Heinrichs-Schreiber zasugerowała wręcz bezpośrednie zetknięcie się Piotra Parlera z dziełem Slutera; eadem, Vincennes, s. 223-225.

119 Ibidem, s. 227-228.

120 Agnieszka Łaguna-Chevilotte wyeksponowała znaczenie figury Madonny ze Zwiastowania z Ecouis, którą wydatowała na lata ok. 1380 r. i uznała za paryski model dla Pięknej Madonny Toruńskiej, podpierając swą argumentację także dalszymi przykładami, jak figura proroka z Museum of Fine Arts w Bostonie. Zasugerowała także zbieżność formalną układu pofałdowań szaty toruńskiej Madonny Brzemiennej 
nych i wobec dyskusyjności datowań - nie ulega raczej wątpliwości, że kreacja Pięknych Madonn jest dziełem czeskim.

Nie zmienia to faktu, że twórczość czeska faktycznie inspirowała się rozwiązaniami z kręgu sztuki francuskiej na długo przed narodzinami Pięknych Madonn. Ślady tej tradycji odnajdujemy w licznych dziełach rzeźbiarskich XIV wieku, jak choćby u mistrza Madonny z Michle. Praga stanowiła jednak ośrodek o odmiennej niż Paryż atmosferze i odmiennej dynamice przemian, na których nie ciążył balast tradycji rzeźby katedralnej czy rzeźby dworskiej XIII wieku. Wydała dzięki temu styl oryginalny i rozpoznawalny ${ }^{121}$, oparty na twórczej parafrazie. Madonna z Ratusza Staromiejskiego, tak bardzo francuska w źródłach ${ }^{122}$, jest przecież kreacją w sensie formy całkowicie nowatorską. Podobnie rzecz ma się z Pięknymi Madonnami - nie tylko pojedyncze motywy, ale całościowa koncepcja estetyczna tych dzieł jest zupełnie odmienna od wcześniejszej francuskiej tradycji. Mimo to, właśnie ona leży u podstaw nowej kreacji ${ }^{123}$, za Beltingiem można ją potraktować jako rodzaj retrospekcji, powrót do archaicznego ideału około 1300 roku, zapewniającego dziełu „kultową autentyczność” ${ }^{24}$.

Przykładem tego zjawiska jest Piękna Madonna Toruńska. Najbardziej konstytutywna cecha typu „prusko-śląskiego” - gest po-

z systemem draperii, rozwiniętym np. w posągu Joanny de Bourbon, przechowywanym w Luwrze; eadem, „Contribution à la recherche sur les Belles Madones et la sculpture française autour de 1400", Mémoire du D.E.A. d'Histoire de l'Art Médiéval 2000/2001, Sous la direction de Monsieur D. Russo, Université de Bourgogne U.F.R. des Sciences Humaines, Département d'Histoire de l'Art et d'Archéologie. W tym miejscu chcę złożyć serdeczne podziękowania Autorce za udostępnienie mi na potrzeby niniejszych badań jej niepublikowanego studium oraz za wartościowe obserwacje, dotyczące Pięknej Madonny Gdańskiej.

121 G. Schmidt, Bewegung und Gegenbewegung. Internationale Gotik versus Schöner Stil, w: Karl IV. Kaiser, s. 541-547.

122 Por. przede wszystkim R. Didier, Contribution à l'étude d'un typ de Vierge française du XIVe siècle. A propos d'une réplique de la Vierge de Poissy à Herresbach, Revue des Archéologues et historienne d'art de Louvain, t. III, 1970, s. 49-72, zwł. s. 70-71. Omówienie problemów stylowych i stanowisk badawczych: M. Hörsch, Stehende Madonna mit Kind vom Altstädter Rathaus im Prag, w: Karl IV. Kaiser, s. 105-107 (nr 30).

123 Francuskie filiacje typologiczne podkreślał R. Suckale, [rec. Clasen], s. 249.

124 H. Belting, Image et culte, s. 586. 
dawania jabłka Dzieciątku, składającemu na nim rączki, wywodzi się z kameralnej rzeźby francuskiej ${ }^{125}$. Układ postaci Dzieciątka, choć wzmocniony ujmującym je od dołu gestem Marii, ma swe odniesienia $\mathrm{w}$ tradycyjnym francuskim schemacie upozowania, w którym prawa nóżka jest na ogół ugięta w kolanie i wysunięta ku przodowi. Motyw ostentacyjnego podtrzymywania nóżki Dzieciątka (który, zdaniem Suckalego, można zinterpretować jako „cytat” z wyobrażeń typu Pietá $\left.{ }^{126}\right)$, obecny był w rzeźbie francuskiej już wcześniej i miał znaczenie dogmatyczne, oparte na wykładni ojców kościoła o Inkarnacji Chrystusa ${ }^{127}$. Nawet smutek, jakim tchnie przedstawienie (jeden z komponentów typu Pięknych Madonn), jest tylko z pozoru czeskim novum. Przypomnijmy, iż wedle Schwarza, Piękne Madonny były plastyczną odpowiedzią Europy Środkowej na importowane ikony, nie dziwi więc, że są one podszyte archaicznym liryzmem i symboliką bizantyńskiej Eleusy ${ }^{128}$. Podobne odejście od manierycznej stylizacji mimiki znajdujemy już na początku XIV wieku także w szeregu dzieł kamiennych

125 Geneza przedstawienia „zabawy” matki i dziecka wiązana jest z Vierge Dorée w Amiens, niemniej rozwiązanie to znalazło swoją popularność przede wszystkim w rzeźbie w kości słoniowej, gdzie pojawił się i upowszechnił gest podawania Jezusowi owocu. Najsłynniejszy przykład tego rozwiązania stanowi Madonna z SainteChapelle (obecnie w Luwrze, OA 57). Francuska tradycja najprawdopodobniej dała też impuls popularności motywu w kręgu Madonn na Lwach.

126 Zob. R. Suckale, Die Sternberger Schöne Madonna, s. 94.

127 Począwszy od Cyryla Jerozolimskiego (IV wiek), który wyłożył dogmatyczną symbolikę ciała Chrystusa, stopy Zbawiciela związano symbolicznie $\mathrm{z}$ jego człowieczeństwem: F. Baron, La Vierge à l'Enfant, w: L'art aux temps des rois maudits Philippe le Bel et ses fils 1285-1328 (kat. Paris, Galeries nationales du Grand Palais, red. D. Gaborit-Chopin, Paris 1998, s. 136 ( $\mathrm{nr}$ 81); eadem, La statuaire mariale dans le départament de l'Oise à la fin du XIII et au XIVe siècle, w: L'art gothique dans l'Oise et ses environs (XII ${ }^{e}-X I V^{e}$ siècle). Architecture civile et religieuse, peinture murale, sculpture, des arts précieux etc. Colloque international à Beauvais 1991, red. A. Erlande-Brandenburg, Beauvais 2001, s. 191-205, zwł. s. 200. Gest prezentacji stopy Jezusa przez Marię znajdujemy w całym szeregu kamiennych o rzeźb oraz ivoirów z XIII i XIV w.; zastosowanie tego motywu zaowocowało wykształceniem samodzielnego typu maryjnego w sztuce Ile-de-France (np. Madonna w kościele St. Lambert w Varenne-sur-Seine, a w regionie Oise figury Madonn w Hôpital Général w Senlis, w Talmontiers und Mesnil-en-Thele. Ibidem, s. 200-201.

128 M. V. Schwarz, Schöne Madonna, s. 91. 
z terenów Ile-de-France, Szampanii, Burgundii ${ }^{129}$ czy u Madonn lotaryńskich ${ }^{130}$, których znaczenie dla formowania zjawisk artystycznych w Europie Środkowej nie zostało jeszcze dostatecznie wyakcentowane. Nawiązanie do znanych wcześniej motywów nie umniejsza jednak faktu, że każdy element formy Pięknej Madonny Toruńskiej (począwszy od kompozycji bryły a skończywszy na ideale urody) złożył się tu na nowatorskie oddziaływanie wizualne - pozbawione typowych dla XIV wieku cech teatralnej prezentacji.

W przypadku Pięknej Madonny Gdańskiej stosunek do francuskiej tradycji jest odmienny - twórcza retrospekcja zmienia się w konserwatywną „regotycyzację”. Choć zapewne rzeźba ta służyła początkowo pozaliturgicznej czci maryjnej, w swym wyjątkowym monumentalizmie daleka była od subtelnej obecności innych pokrewnych figur w przestrzeni kościoła, a bliższa kultowym wyobrażeniom francuskim z przełomu XIII i XIV wieku ${ }^{131}$. Sztywność ujęcia, zwartość bryły czy typ Dzieciątka także wyłamują tę rzeźbę z grona Pięknych Madonn. Choć w starszej literaturze odrębności te tłumaczono północnym charakterem figury ${ }^{132}$, Didier i Recht jako pierwsi podnieśli możliwość jej

129 Np. rzeźby Madonn z 2 ćw. XIV w. z terenów Ile-de-France i Szampanii, przechowywane w Luwrze (nr. inw. RF2534 i RF1398), znajdujące się tamże dzieła burgundzkie - Madonna z Dzieciątkiem (RF 2880), Tronująca Madonna z regionu Joigny (RF 1486), Maria depcząca po bazyliszku z okolic Sens (RF 1390); a także kultowa rzeźba tronującej Madonny z ok. 1334 r., czczona w katedrze w Sens.

130 Także w tej grupie nostalgia oblicza jest cechą konstytutywną: J. Schmoll gen. Eisenwerth, Zur lothringischen Skulptur des 14. Jahrhunderts, w: Lothringische Skulptur, s. 7-16, zwł. s. 12.

131 Jak Madonna z konwentu cystersów w Fontanay o wysokości 2 m czy Vierge de Bayeul o wys. 1,72 m.

132 Wpływ lubecki proponował B. Schmid, Die bildende Kunst in Preußen zur Zeit des deutschen Ritterordens, w: Die Provinz Westpreußen in Wort und Bild, 2 Teil - Einzelldarstellungen, 2. Aufl., Danzig 1915, s. 449-459, zwł. s. 447. Pinder widział w niej syntezę wpływów czeskich, reprezentowanych przez Piękną Madonnę Toruńską oraz hanzeatyckich: W. Pinder, Die deutsche Plastik, s. 240-241. Na "charakter północny” dzieła, zdecydowanie odmiennego od sztuki czeskiej, wskazał też P. Abramowski, Danziger Plastik von der Mitte des 14. Jahrhunderts bis zum Beginn der Renaissance, Leipzig 1926, s. 49-52. O przekształceniu formy w duchu mieszczańskim (Verbürgerlichung) pisał też A. Feulner, Der Meister der Schönen Madonnen, "Zeitschrift des deutschen Vereins für Kunstwissenschaft” 1943, t. X, z. 1/2, s. 19-48, zwł. s. 32. 
zachodniej proweniencji ${ }^{133}$. To jej wynikiem jest kompozycja oparta na schemacie litery $\mathrm{C}$, podporządkowująca obie postaci jednemu płynnemu kierunkowi, która tkwi korzeniami w rzeźbie w kości słoniowej. Podobnie jak Madonny francuskie XIII i XIV wieku, Maria gdańska wysoko na ramieniu podtrzymuje Dzieciątko, częściowo okryte draperią, nieforemnie zbudowane, nieproporcjonalnie małe i na tyle pozbawione naturalnego ciężaru, by mogło być lekko uniesione na jednej ręce. Charakterystyczny układ postaci Jezusa, który wyprostowaną lewą rękę wyciąga nad atrybutem, nie dotykając go, nawiązuje typologicznie do najczęstszego upozowania u figur francuskich, ostentacyjność zaś tego gestu przywodzi na myśl typ przedstawienia Madonny, trzymającej $p y$ xidę, którą Dzieciątko błogosławi ${ }^{134}$.

Do tradycji francuskiej sięga sposób przedstawienia Marii ukazanej w dworskim stroju o cechach mody aktualnej i włosach, opadających na piersi długimi falami o postrzępionych pierścionkowato kosmykach ${ }^{135}$. W przedstawieniach francuskich znajdujemy zastosowany w gdańskiej rzeźbie schemat ułożenia draperii płaszcza Madonny, przytrzymywanego i komasującego się do formy festonu po stronie usadowienia Jezusa. Jest to dużo bardziej logiczne niż u rzeźb z Torunia czy Sternberka, ale też pozbawia gdańską figurę wystudiowanej per-

133 R. Didier, R. Recht, Paris, Prague, Cologne, s. 146 ; R. Recht, La sculpture, s. 103.

134 Gest ten można interpretować jako prefigurację ofiary Chrystusa oraz symbol Eucharystii. Wariant ten zapoczątkowała figura Madonny z konwentu cysterskiego w Pont-aux-Dames (Seine-sur-Marne), z 2 ćw. XIV w. F. Baron, La Vierge à l'Enfant, w: Les fastes du Gothique, s. 91-92 ( $\mathrm{nr} 6$ ).

135 O znaczeniu stroju i uczesania Madonny gdańskiej: M. Hasse, Studien zur Skulptur des ausgehenden 14. Jahrhunderts, „Städel-Jahrbuch” 1977, NF 6, s. 99-128, zwł. s. 125. Geneza motywu tak uformowanych pukli włosów tkwi w sztuce André Beauneveu i została przejęta przez szereg naśladujących jego dzieło figur Madonn z Dzieciątkiem, jak np. rzeźba z Monceau-le-Compte z około 1380 roku, uważana za pochodną figury św. Katarzyny w Courtrai. Por na jej temat: F. Baron, La Vierge allaitant l'Enfant, s. 141 (nr 90) - naśladownictwo Madonny z Cour-Dieu, nawiązujące do rzeźby św. Katarzyny w Coutrai; D. Borlée, La Vierge allaitant l'Enfant, w: Les princes des fleurs de lys. L'art à la cour de Bourgogne. Le mécénat de Philippe le Hardi et de Jean sans Peur (1364-1419), (kat. wystawy Dijon, Musée des Beaux Arts / Cleveland, The Cleveland Museum of Art), red. Stephen N. Fliegel, Sophie Jugie, Paris 2004, s. 313-134 (nr 118): le reflet de la sainte Catherine de Coutrai. 
fekcji amorficznych szat, które uważane są za jeden z wyznaczników kręgu Pięknych Madonn ${ }^{136}$. Z kolei ideał urody Marii, o lekko opuchniętej twarzy, daleki od czeskiego kanonu z około 1400 roku, tkwi być może korzeniami w sztuce Jeana de Marville, który miał też wpływ na burgundzkie dzieło Slutera ${ }^{137}$ - stąd nie dziwią dalekie analogie fizjonomiczne dla figury gdańskiej, jakie znajdujemy u Madonny z portalu kaplicy książęcej w kartuzji Champmol w Dijon ${ }^{138}$. Co ważniejsze, podczas swego długiego pobytu w Brugii, Marville uformował charakterystyczną naturalistyczną tendencję, czytelną w rzeźbie niderlandzkiej. Zogniskowała się ona w wykonanej w latach 80. XIV wieku SintDonaas-Madonna z Brugii, wiązanej ostatnio z wczesną fazą twórczości Slutera w Dijon ${ }^{139}$. Ta właśnie rzeźba wskazywana była przez Gerharda Schmidta ${ }^{140}$ jako formalna antycypacja Pięknej Madonny Gdańskiej, której autorstwo Didier przypisał wędrownemu artyście, przybyłemu z Brugii i osiadłemu na Pomorzu ${ }^{141}$.

136 Zob. analiza porównawcza systemu draperii francuskich Madonn XIV-wiecznych oraz Pięknych Madonn, G. Winter, Zur Sinnbestimmung, s. 2-4; H. Bredekamp, H. Beck, Der internationale Stil, s. 69-70; M. Hasse, Studien zur Skulptur, s. 118-120.

137 O formacji artystycznej Clausa Slutera: R. Didier, Claus Sluter. A l'occasion de l'exposition au Musée des Arts Anciens de Namurois (26 VI-22 VIII 1993), Namur 1993 (Publication extraordinnaire de la Société archéologique de Namur), s. 17; F. Joubert, Illusionisme monumental à la fin du XIVe siècle. Les recherches d'André Beauneveu et de Claus Sluter à Dijon, w: Pierre, lumière, colour. Etudes d'histoire de l'art du Moyen Age à l'honneur de'Anne Prache, red. F. Joubert, D. Sandron, (Culture et Civilisation médiéval XX), Paris 1999, s. 367-384.

138 Wpływ taki sugerował M. Hasse, Studien zur Skulptur, s. 125, widząc w gdańskiej Madonnie przykład typu, jaki ukształtował się w Niderlandach i środkowej Francji pod wpływem Slutera.

139 H.Nieuwdorp, Viergeàl'Enfant, w:Lesprincesdesfleursdelys, s. 67-68(nr20).

140 G. Schmidt, [rec. Clasen], s. 80.

141 Np. R. Didier, R. Recht przypisali figurę mistrzowi flandryjskiej formacji, realizującemu styl o genezie paryskiej; R. Didier, R. Recht, Paris, Prague, Cologne, s. 146; R. Didier, De H. Cornelius van het Sint-Janshospitaal en de Brugse beeldhouwkunst omstreeks 1400, w: Rond de restauratie van het 14de-eeuwse corneliusbeedl, Brugge 1984, s. 19-52, zwł. s. 31. Gdańska Piękna Madonna jest jego zdaniem bliska sztuce brugijskiej. Jej autor mógł być czynny w ośrodkach Hanzy w latach 1410-1420; sposób nawiązania do schematu Pięknych Madonn jest analogiczny, jak ołtarzu z Bokel (Hannover, Niedersachsische Museum, ok. 1420); R. Didier, Le style international des 
$\mathrm{Na}$ temat powierzchowności analogii, łączących oba dzieła, pisałam już $\mathrm{w}$ innym miejscu ${ }^{142}$. Wypada przypomnieć, że w kręgu niderlandzkim szeregu dużo dokładniejszych analogii dostarcza raczej dębowa rzeźba Madonny z Dzieciątkiem z Ankeveen koło Hilversum (Rijksmuseum w Utrechcie, il. 5), wykonana prawdopodobnie w Utrechcie około $1430 \mathrm{roku}^{143}$. Obie figury realizują ten sam model, tyle że w innej skali, w różnym materiale, zaś kompozycyjnie - w odbiciu lustrzanym. Jedyna istotna różnica obrazowa pomiędzy nimi tkwi w sposobie ujęcia postaci Dzieciątka, które u Madonny z Ankeveen jest większe, dużo „ruchliwsze” i całkowicie nagie, a więc pod tym względem wierniejsze kanonowi Pięknych Madonn. Poza tym dzieła łączy analogiczna kompozycja, zwarta tektonika bryły, rzut draperii płaszcza, linearny, skomplikowany rysunek płaskiej kaskady bocznej, wreszcie szczegóły - kostium, typ twarzy Marii czy manieryczny układ jej dłoni (z charakterystycznie odgiętym małym palcem). Obie rzeźby realizują późną fazę stylu pięknego, nacechowaną zwartą bryłą, powieleniem płaskich pofałdowań szat oraz dość graficznym modelunkiem. Miękkość i płynność draperii u figury gdańskiej może wskazywać na jej nieco wcześniejszą metrykę lub stanowić wynik zastosowania kamienia.

Zastanawiająca w tym zestawieniu jest jednak inwersja póz. Umieszczenie Jezusa na prawym ramieniu Marii gdańskiej jest na tle kręgu Pięknych Madonn unikalne ${ }^{144}$, a w całej rzeźbie średniowiecznej

années 1400, w: L'art flammand et hollandais. Le siècle des primitifs 1380-1520, red. Ch. Heck, Paris 2003, s. 477-489, zwł. s. 477-478.

142 M. Jakubek-Raczkowska, Rzeźba gdańska przełomu XIV i XV wieku, s. 82-83.

143 Het Catharijnenconvent, nr inw. ABM494. Na temat datowania por. J. Steyaert, Standing Virgin and Child from Ankeveen, w: Late Gothic Sculpture in Burgundian Netherlands (kat. wystawy Gent, Museum voor Schoone Kunsten), red. J. Steyaert, Ghent 1994, s. 290 (nr 81); tu także pierwsze sugestie o związku z Gdańskiem; M. Van Vliedern, H. L. M. Defoer, H. M. E. Höppener-Bouvy, Hout- en steensculptuur van Museum Catharijneconvent ca. 1200-1600, Zwolle-Utrecht 2004, s. 84-85 (autorzy uważają rzeźbę za typowy przejaw stylu międzynarodowego, także wskazują na powinowactwo z Madonną gdańską). Uszczegółowiona analiza Madonn z Ankeveen i Gdańska zob. M. Jakubek-Raczkowska, Rzeźba gdańska przełomu XIV i XV wieku, s. 83-84.

144 Clasen tłumaczył to tradycją lokalną Madonn na lwach; K. H. Clasen, Die mittelalterliche Bildhauerkunst, s. 146. Prawostronne umieszczenie Dzieciątka jest dość często spotykane wśród Madonn na lwach. W Prusach reprezentują ten motyw 
raczej rzadkie. W ujęciu tym znikają symboliczne konotacje związane z usytuowaniem Marii po prawicy Chrystusa ${ }^{145}$, nienaturalnie działa wyciągniecie lewej rączki Jezusa ku atrybutowi, słabnie też sugerowana wyżej „liturgiczna” wymowa tego gestu. Niewykluczone więc, że gdańska Piękna Madonna jest transpozycją wzorca, wykonaną przy użyciu zwierciadła ${ }^{146}$ - pomiędzy rzeźbą a jej modelem stałby więc rysunek. To tłumaczyłoby, dlaczego charakterystyczny łukowaty układ ciała Marii gdańskiej, bazujący na francuskich ivoirach, jest wobec swych pierwowzorów odwrócony; stawiałoby zarazem pod znakiem zapytania ewentualny import tej rzeźby z Niderlandów.

Fakt, że warsztaty północnoniderlandzkie na import pracowały, potwierdzają istniejące nawiązania do typu Madonny z Ankeeven. Powtarzają one tradycyjny układ kompozycyjny, z usadowionym na lewym ramieniu matki, całkowicie nagim Dzieciątkiem, upozowanym dynamicznie, jak u środkowoeuropejskich Pięknych Madonn. Tak jest w przypadku tzw. Virgen del Pimiento - drewnianej rzeźby z klasztoru klarysek w Calabazanos koło Palencji ${ }^{147}$. Jej utrechcką genezę tłu-

dwie rzeźby o modelowym znaczeniu, które dały początek grupom naśladownictw: Madonna stojąca na lwie z Lubieszewa oraz tronująca Madonna z Jeziernika, zob. M. Jakubek-Raczkowska, Rzeźba gdańska przełomu XIV i XV wieku, s. 49-57. Źródłem tego ujęcia wydaje się układ tronującej Madonny ze Skarbimierza. Z kolei zdaniem Kutala prawostronne umieszczenie Jezusa gdańskiego to wynik wpływu tradycji przedparlerowskiej: A. Kutal, Ein neues Buch, s. 558.

145 F. Baron, La statuaire mariale, s.192. Unosząc Dzieciątko na lewej ręce (po stronie serca), Maria znajduje się po jego prawicy (co znajduje analogie w wyobrażeniach Koronacji Marii i ma symboliczne odniesienia do psalmu 44).

$146 \mathrm{Na}$ istnienie średniowiecznej praktyki odwzorowywania modeli rzeźbiarskich w wypukłym zwierciadle - także w początku XV wieku - wskazał J. Wirth, Copie en miroir - copie au miroir?, w: Materiam superabat opus. Hommage à Alain Erlande-Brandenburg, red. A. Bos, X. Dectot, J.-M. Leniaud, P. Palgnieux, Paris 2006, s. $265-277$.

147 Obecnie w Museo Mares w Barcelonie (nr MFMB 1079). Przez Steyaerta datowana jest ona $\mathrm{z}$ dużą dozą prawdopodobieństwa na lata tuż przed $1435 \mathrm{r}$. i uznana za kopię według dzieła utrechckiego, zob. J. Steyaert, Standing Virgin, s. 290. Geneza fundacji tej rzeźby wiąże się według niego z zaślubinami konstabla Alvaro de Luny i Juany Pimentel w 1435 r. Zwraca uwagę fakt, iż literatura hiszpańska datuje tę rzeźbę dużo później, na ok. 1500 r., ale także wskazuje na niderlandzką proweniencję, por. m.in.: Museo Federico Marés Deulovol, Declarado Monumanto Histórico-Artístico, Catalogo, Barcelona 1979, s. 60 (nr 1.899): rzeźba określona jako praca hiszpańska 
maczą liczne związki - także artystyczne - pomiędzy Niderlandami a Hiszpanią ${ }^{148}$ (być może to za ich właśnie przyczyną zbliżona stylistycznie do rzeźby gdańskiej figurka Marii ze Zwiastowania ${ }^{149}$ trafiła do Barcelony). Kolejnym powtórzeniem typu jest niewielka rzeźba Madonny w Suermondt-Ludwig Museum w Aachen ${ }^{150}$, już o cechach stylu łamanego, dość swobodnie interpretująca utrechcki model. Wyraźne echa tego ujęcia znajdujemy wreszcie w rzeźbionej w drewnie Madonnie w kościele św. Macieja w Trewirze z lat około 1450-1460, wykonanej prawdopodobnie w Utrechcie dla opactwa, utrzymującego silne związki z północnymi Niderlandami ${ }^{151}$ (il. 6). Za pomocą środków stylu łamanego zrealizowano tu niezwykle bliski omówionym wyżej przykładom wariant typologiczny, choć kompozycja jest nieco sztywniejsza, a przez to bardziej prezentacyjna. Pod względem układu postaci rzeźba trewirska wydaje się bliższa figurze z Ankeveen niż z Gdańska, Jezus jest jednak sztywny i nieruchomy jak u Marii gdańskiej; majestatycznym, „konsekracyjnym” ruchem wyciąga dłoń ku atrybutowi, którym jest u trewirskiej rzeźby winne grono. Zbieżność układu palców może zresztą świadczyć, że atrybut Pięknej Madonny Gdańskiej też był podobny (jej lewa dłoń jest inaczej ułożona, niż gdyby miała ujmować jabłko na

pod wpływami niderlandzkimi, ok. 1500. Fons del Museu Frederic Marès, 1. Catàleg d'escultura i pintura medievals, red. E. i B. Francesca, Y. L. Joaquín, Barcelona 1988, nr 126: rzeźba określona jako import brabancki około $1500 \mathrm{r}$.

148 Związki artystyczne pomiędzy Niderlandami i Półwyspem Iberyjskim naświetlono niedawno w publikacjach: Ao modo da Flanders. Disponibilade, inovaçăo e mercado da arte (1415-1580). Actas do Conresso Internacional celebrado em a reitoria da Universidade de Lisboa, red. B. Garcia García, Lisboa 2005; G. C. J. Ara, El problema de la delitación entre lo flamenco y lo hispánico en la escultura castellana del siglo XV, w: El arte en la corte de los reyes católicos. Rutas artistísticas a principios de la Edad Moderna, red. F. Checa, B. García García, Madrid 2005, s. 223-247.

149 Z Madonną gdańską związął ją E. M. Vetter, Die Verkündigungsmaria aus dem Umkreis des Meisters des Danziger Schönen Madonna, „Das Münster” 1968, nr 21, s. 181-190, zwł. s. 183-189. Atrybucja ta nie wydaje się jednak przekonywająca, obie figury różnią się bowiem ogólną koncepcją formalną, łaczą je tylko niektóre szczegóły (ogólny typ twarzy Marii, fryzura, polichromia). Wspólna jest zapewne ich geneza formalna.

150 J. Steyaert rozpoznaje w tej figurze ogniwo pośrednie pomiędzy rzeźbami z Ankeveen i Trewiru, datuje na ok. 1450 r.; J. Steyaert, Standing Virgin, s. 294.

151 Rzeźbę tę łączą z Madonną z Ankeveen: J. Steyaert, Standing Virgin, s. 294; M. van Vliedern, H.L. M.Defoer,H.M.E.Höppener-Bouvy, Hout-ensteensculptuur, s. 85. 
wzór Madonny toruńskiej). Figura w Trewirze kontynuuje dostojny typ wizerunku kobiecego o nabrzmiałym owalu twarzy, opuszczonych powiekach i drugim podbródku. Podobny kanon urody i mimiki, przy jednoczesnym hieratyzmie postawy i manierycznych gestach, znajdujemy również w coraz późniejszych dziełach utrechckich, np. u łączonej z Janem Nude Madonny w typie Niewiasty Apokaliptycznej z lat 1470-1480 (obecnie w Luwrze, il. 7) ${ }^{152}$, która - choć w koncepcji i formie już odmienna - zachowuje specyficzny dla dzieł z Gdańska i Ankeveen ideał urody i sztywność prezentacji.

Pozostaje kwestia rozstrzygnięcia miejsca i roli figury gdańskiej w tym typologicznym ciągu rozwojowym. Madonna z Ankeveen jest uważana za lokalną, niderlandzką odmianę typu Pięknych Madonn, opartą na modelu toruńskim. Steyaert, przyjmujący datowanie gdańskiej figury na lata 1410-1420, widział w niej antycypację dzieł utrechckich, nie tłumacząc jednak charakteru ewentualnych powiązań ${ }^{153}$. Wyraźnie zachodnia formacja Pięknej Madonny Gdańskiej wskazuje, że jej twórca trafił do Prus z zewnątrz, podobnie jak wzmiankowany w źródłach gdańskich Jan van der Matten, bildinsnyder aus Flandern ${ }^{154}$. Czy przyjąć więc - idąc za metodą Clasena - że po zetknięciu się z toruńskim pierwowzorem podjął dalszą wędrówkę, przenosząc nowy model do Niderlandów? Czy raczej szukać wspólnego ogniska zarówno dla Gdańska, jak i dla Ankeeven? Uważam, że z uwagi na silne przenikanie się rozwiązań stylu międzynarodowego, ta kwestia musi pozostać otwarta. Także w przypadku dzieł zachodnich brak bowiem jednoznacznych ustaleń genetycznych, przez co poszukiwanie ewentualnych wcześniejszych ogniw stylowych jest znacznie utrudnione.

Wystarczy wspomnieć kontrowersyjną „Piękną Madonnę” z kościoła św. Serwacjusza w Maastricht, wykonaną w drewnie i - podobnie

152 Pochodzi z kolekcji Emila Charlesa Wautersa. Paryż, Musée du Louvre, nr inw. RF 2319. Na temat atrybucji por. Adriaen van Wessel - een Utrechts beeldhouwer uit de late middeleeuwen (kat. Wystawy Amsterdam, Rijsksmuseum), red. W. Halsema-Kubes, G. Lemmes, G. De Werd, Amsterdam 1980, s. 22 (De Utrechtse kunst voor Adriaen van Wesel).

153 J. Steyaert, Standing Virgin, s. 290.

154 B. Schmid, Maler und Bildhauer in Preußen von 1350 bis 1450, „Altpreußische Forschungen”, Bd.2, 1925, s. 39-52, zwł. s. 48. 
jak figura gdańska - odstępującą w szczegółach od swych pierwowzorów. Uważana jest ona za dzieło nadreńskie lub niderlandzkie. Przez Clasena uznana niesłusznie za snycerską kopię według nieznanego wzorca spod dłuta głównego „mistrza Pięknych Madonn”"155, stanowi ona raczej późną, już XV-wieczną kontaminację różnych wariantów ${ }^{156}$, której genezy formalnej nie sposób dowieść. Takie szczegóły, jak dekoracyjna korona, winogrono w dłoni, przesłonięcie nagości Dzieciątka, wywodzą się z tradycji zachodniej, na którą nałożony został schemat kompozycyjny Pięknej Madonny Toruńskiej, pod względem formalnym poddany rygorowi płaskiej dekoracyjności. Zarówno ten rodzaj kontaminacji, jak i wertykalizm kompozycji figury w Maastricht przywodzi na myśl Marię gdańską, na co zwrócił uwagę Zygmunt Kruszelnicki ${ }^{157}$.

Pewne cechy stylistyczne, typowe dla Pięknej Madonny Gdańskiej, znajdujemy też $\mathrm{w}$ grupie środkoworeńskich rzeźb z terrakoty, jakie Wilm zgrupował wokół Madonny z Hallgarten (1415-1420) ${ }^{158}$ - il. 8. Dostarczają one analogii dla rozwiązania kostiumologicznego o franko-flamandzkiej genezie (przepasany wysoko houppelande) oraz dla swobody płynnej, dość ciężkiej draperii. Wprawdzie nacechowane są większym liryzmem i optyczną ruchliwością ujęcia, ale zdradzają podobne, „zachodnie” odczucie stylowe, tylko pozornie bliskie stylowi Pięknych Madonn ${ }^{159}$. Zwraca również uwagę dostojny ideał urody Marii z Hallgarten (owalna, lekko nabrzmiała twarz), uformowanie korony o wysokich, bardzo plastycznych fleuronach (jak u Marii gdańskiej), owoc winnego grona jako atrybut w ręku Jezusa. Rzeźby z tego kręgu do-

155 K. H. Clasen, Der Meister, s. 31-32.

156 A. Kutal, Ein neues Buch, s. 545. Zob. także: S. Schürmann, hasło kat., w: Die Parler, Bd. 1, s. 118.

157 Z. Kruszelnicki, „Piękne Madonny” - problem otwarty, s. 49.

158 M.in. Madonna $z$ Eberbach im Rheingau (obecnie w Luwrze), Madonna z Drommersheim (zaginiona), św. Barbara i św. Katarzyna w Bingen: H. Wilm, Gotische Tonplastik in Deutschland, Augsburg 1929, s. 64-67. Zob. także: Muttergottes aus Hallgarten, hasło kat., w: Kunst um 1400 am Mittelrhein, s. 152 (nr 72).

159 O różnicach w stosunku do grupy Pięknych Madonn zob. S. Guillot de Souduirout, Sculptures allemandes de la fin du Moyen Age dans les collections publiques françaises 1400-1530 (kat. wystawy Luwr), Paris 1991, s. 62-65 (La Vierge à l'Enfant sur le croissant de lune). 
czekały się różnych interpretacji - choć traktowane są jako lokalny wytwór nadreński ${ }^{160}$, wskazuje się też na silny pierwiastek niderlandzki ${ }^{161}$. Analogie, jakie łączą model Madonny gdańskiej z nieco wcześniejszą rzeźbą z Hallgarten, znajdujemy też u pozostającej do niedawna w zapomnieniu figury Matki Bożej z Dzieciątkiem z katedry fromborskiej $^{162}$, wykonanej w kamieniu i osiągającej monumentalne rozmiary (il. 9). Uchodziła ona dotąd uwadze badaczy, gdyż do czasów Clasena zaopatrzona była we wtórną głowę, a z działań wojennych wyszła w stanie destruktu ${ }^{163}$. Przeprowadzone niedawno prace konserwatorskie ujawniły wreszcie niezaprzeczalną klasę tego dzieła, a także jego bliskie pokrewieństwo w stosunku do Madonny z Gdańska ${ }^{164}$. Choć rzeźba fromborska prezentuje odmienny typ obrazowy, tzw. „Madonny w otwartym płaszczu”, on także tkwi korzeniami w tradycji francuskiej ${ }^{165}$. Podobnie jak figura gdańska, rzeźba z Fromborka czerpała inspiracje z Pięknych Madonn - na co wskazuje ujęcie nagiego, miękko modelowanego ciała Jezusa. Trudno byłoby zaliczyć ją jednak do tego kręgu, mimo ewiden-

160 Muttergottes aus Hallgarten, s. 152.

161 S. Guillot de Souduirout wskazuje na sięgnięcie do francuskiego typu Madonny w otwartym płaszczu oraz charakterystyczny dla Niderlandów, płynny sposób modelowania szat (jak u Madonny $\mathrm{z}$ alabastru w zbiorach amsterdamskich, w rzeźbach świętych w ołtarzu Jaques'a de Baerze w Dijon, u figur utrechckich z terakoty) oraz analogie kostiumowe. Wspomniane figury Madonn prezentują popularny później w Utrechcie typ Niewiasty Apokaliptycznej, stąpającej po półksiężycu, atrybutem Dzieciątka jest winne grono. S. Guillot de Souduirout, Sculptures allemandes, s. 64.

162 Figura jest własnością Muzeum Mikołaja Kopernika we Fromborku.

163 Nie istnieje głowa Marii ani jej lewa dłoń, prawa jest uszkodzona; z postaci Dzieciątka zachował się tylko fragment rączki. Obecnie figura mierzy $157 \mathrm{~cm}$ x 60 x $55 \mathrm{~cm}$.

164 Za zwrócenie mojej uwagi na fromborską rzeźbę i zaproszenie do konsultacji merytorycznych serdecznie dziękuję pani mgr Magdalenie Szewczyk, absolwentce Akademii Sztuk Pięknych w Warszawie, której zasługą jest przywrócenie figurze jej właściwego miejsca w dziejach sztuki pomorskiej przez opracowanie historii dzieła i przeprowadzone przy nim pieczołowite zabiegi konserwatorskie. Ich efekty zostały omówione przez autorkę konserwacji w pracy dyplomowej, cz. I: „Konserwacja i restauracja figury Marii z Dzieciątkiem ze zbiorów Muzeum Mikołaja Kopernika we Fromborku” pod kierunkiem dr. adi Krzysztofa Chmielewskiego i adi Wiesława Procyka, cz. II: „Wokół późnogotyckiej kamiennej figury Marii z Dzieciątkiem z Fromborka", pod kierunkiem dr. adi Krzysztofa Chmielewskiego, ASP Warszawa 2009.

165 To właśnie ujęcie reprezentują wspomniane rzeźby z kręgu Madonny w Hallgarten, w analogiczny sposób podtrzymujące Dzieciątko. 
tnych cech stylu miękkiego. Maria o długich, rozpuszczonych włosach, upozowana jest tu sztywno, frontalnie i pozostaje całkowicie bierna, podczas gdy to Dzieciątko (obojętne całkiem na widza) wczepiało się w połę jej płaszcza ${ }^{166}$.

Zbieżność obu pruskich figur przejawia się nie tylko w usztywnieniu kompozycji i zdystansowanej relacji pomiędzy postaciami, ale i w opracowaniu licznych detali ${ }^{167}$. Zwraca jednak uwagę większa przestrzenność bryły fromborskiej - bardziej miękkie, plastycznie modelowane układy szat, nieco cięższe i regularne w partii spływów (co czytelne jest przy porównaniu kaskad), za to drobniej i bardziej dekoracyjnie rozłożone na podstawie. Figura fromborska bliższa jest przez to Marii z Hallgarten czy św. Barbarze z Bingen, niż nieco późniejszej figurze z Ankeveen. Trudno zaryzykować więc tezę o tożsamej ręce mistrza, ale wydaje się, że obie rzeźby - fromborska i gdańska, przez swe rozmiary i ujęcie tak wyjątkowe w sztuce państwa zakonnego - powstały w tej samej pracowni o zachodnich tradycjach.

Uprawomocnia to postawioną przeze mnie wcześniej tezę o wykonaniu Madonny gdańskiej na terenach państwa zakonnego ${ }^{168}$, w przeciwieństwie do grupy dzieł czeskich. Lokalna recepcja prezentowanych przez obie rzeźby form jest jednak słabo uchwytna. Być może z inspiracji tym ujęciem wyrosła hieratyczna rzeźba Madonny z elewacji połu-

166 Dzieciątko, trzymając w lewej rączce drobny owoc granatu, prawą dłonią przytrzymywało się poły płaszcza Matki, podążając za XIV-wiecznymi wzorcami francuskimi, jak figura Madonny w berlińskim Bodemuseum. Podobny układ Dzieciątka, a także rzadki gest Marii, która miast trzymać w prawej ręce atrybut, podbiera draperię płaszcza, pojawia się też w kręgu Hansa Multschera (np. Madonna w kościele par. w Landsberg ok. 1435 r., czy wykonana przez naśladowcę Madonna w Badisches Landesmuseum w Karlsruhe). Wobec niderlandzkiej formacji Multschera, nie można wykluczyć, że koncepcja Madonny fromborskiej wyrosła z tej samej tradycji.

167 Madonna $\mathrm{z}$ Fromborka odziana jest w suknię, promieniście ułożoną ponad paskiem, zdobionym analogicznymi jak u rzeźby gdańskiej, metalowymi aplikacjami, ujawnionymi dzięki pracom koserwatorskim (klamra już nie istnieje); na ramiona i piersi spływają drobne, wijące, płasko kształtowane pukle włosów o pierścionkowatych kosmykach; drobne detale dłoni (paznokcie, fałdki skóry na kłykciach) modelowane są równie finezyjnie, co naturalistycznie, jak u Marii gdańskiej.

168 M. Jakubek-Raczkowska, Rzeźba gdańska przełomu XIV i XV wieku, s. 85. 
dniowej kościoła Mariackiego w Gdańsku ${ }^{169}$, figura Madonny w otwartym płaszczu w tamtejszej kaplicy św. Jerzego ${ }^{170}$ czy figury z Domnowa i Kalinówki ${ }^{171}$ - te luźne skojarzenia obrazowe nie dają jeszcze postaw do konkretnych wniosków warsztatowych. Dalszy rozwój typu gdańskiej Pięknej Madonny nastąpił nie na Pomorzu, a w północnych Niderlandach.

Rozważania nad rolą Pięknych Madonn w Prusach zamyka Madonna Bractwa Maryjnego w kościele NMP w Gdańsku. Jej ujęcie kompozycyjne powraca do tradycyjnego, XIII-wiecznego schematu: Matka Boża unosi na prawym ramieniu Dzieciątko; w lewej ręce, wysuniętej dla równowagi lekko w bok, trzymała berło lub jabłko. Ten tradycyjny układ pojawił się około 1400 roku zarówno w rzeźbach z młodszej generacji Pięknych Madonn ${ }^{172}$, jak i w malarstwie czeskim ${ }^{173}$. Pod względem formy Madonna Bractwa Maryjnego należy natomiast do

169 Obecnie w Muzeum Miasta Gdańska. Ta dość dobrej klasy figura wydaje się oparta na szeregu rozwiązań typologicznych, czerpanych z różnych źródeł. Osiowość i hieratyzm ujęcia, pewna zwartość kompozycji oraz gest prawej dłoni przywodzą na myśl Piękną Madonnę Gdańską.

170 Umieszczona na ścianie północnej kaplicy bractwa św. Jerzego, sztywna w ujęciu, osadzona już w lokalnej tradycji Gdańska. Płynna kompozycja oparta na literze C, lekki sposób podtrzymywania Dzieciątka i jego gestykulacja, skromne sfałdowanie maforium, są być może echami Pięknej Madonny Gdańskiej, a sposób drapowania płaszcza - Madonny fromborskiej.

171 Zob. M. Jakubek-Raczkowska, Rzeźba gdańska przełomu XIV i XV wieku, s. 85.

172 Przykładem tej przemiany na gruncie czeskim są przede wszystkim Piękne Madonny z Vimperka oraz Chlum nad Ohří, datowane przez Homolkę po 1400: Homolka Jaromir, hasła kat., w: Die Parler, Bd. 2, s. 691-692. Do późniejszych przykładów tego wariantu należy Madonna nieznanego pochodzenia w Kunstmuseum Düsseldorfie (ok. 1410 r.) oraz śląskie figury z Ciechowa (ok. 1410-1420) i Złotoryi (ok. 1430 r.), przechowywane w Muzeum Narodowym we Wrocławiu.

173 Przykładowo w Libellus de fuga saeculi Jana z Jeřeni (Biblioteca Vaticana, Sign.1122, Folio 267) znajduje się miniatura incipitowa, prezentująca tradycyjny wizerunek Marii en pied, trzymającej w dłoni berło i ceremonialnie podtrzymującej Dzieciątko przez połę płaszcza; asystują jej dwaj klęczący aniołowie z insygniami królewskimi. W przykładzie tym cechy obrazowe, kojarzące się z Pięknymi Madonnami (liryczna uroda, nagie Dzieciątko) połączone zostały ze starszą tradycją ikonograficzną. 
czeskich doświadczeń z kręgu figur z Pilzna i Altenmarkt, kontynuuje więc rozwiązania, wypracowane jeszcze w latach $80 .{ }^{174}$

Mimo wczesnej metryki figura ta została celowo umieszczona na końcu niniejszych rozważań. Jej oddziaływanie stanowi bowiem odwrotność zjawiska, związanego z funkcjonowaniem Pięknej Madonny Toruńskiej. Obie te rzeźby były najprawdopodobniej importami z Czech, sprowadzonymi na tereny Prus na fali tej samej artystycznej mody. Przedmiotem lokalnej recepcji stała się jednak tylko praska rzeźba z ołtarza Bractwa Maryjnego. Na pruskiej prowincji zachował się cały szereg naśladownictw tego przedstawienia, które im bardziej w głąb XV wieku i im dalej w głąb państwa zakonnego, tym mniej stawały się wierne ${ }^{175}$. Ta popularność nie była jednak raczej wynikiem prężnej lokalnej działalności jej warsztatu, lecz prawdopodobnie - szczególnej funkcji. Nie można wykluczyć, iż figura Bractwa Maryjnego jest tożsama ze wspomnianym w źródłach wizerunkiem, opatrywanym odpustami ${ }^{176}$, a istnienie wspomnianych naśladownictw ten fakt potwierdza. Na początku XV wieku wciąż aktualna była dawna praktyka powielania modeli kultowych ${ }^{177}$. Być może więc tę właśnie Madonnę naśladowano, próbując zawrzeć w jej schemacie choć cząstkę cudownego przywileju. Drugą przyczyną popularności tego akurat wariantu mogła być jego tradycyjna, łatwo zrozumiała treść. Maria jest tu królową nieba - brak relacji między postaciami zaciera wyrazistość eucharystycznego przekazu nagości Jezusa, a wprowadzenie królewskiego insygnium - ostrość

174 Por. analiza porównawcza: M. Jakubek-Raczkowska, Rzeźba gdańska przełomu XIV i XV wieku, s. 111-112.

175 Np. rzeźba z Osic (Muzeum Narodowe w Gdańsku), z Wapnika (Olsztyn, Kuria Archidiecezji Warmińskiej), Żurawna (Lidzbark, Muzeum Zamkowe), Pogódek (in situ). Szerzej na ich temat: ibidem, s. 117-122.

176 W liście odpustowym biskupa Jakuba von Margarita, związanym z pracami renowacyjnymi i poświęceniem kaplicy w roku 1478, jest mowa o 40 dniach odpustu dla każdego, kto zasłuży się dla kaplicy poprzez modlitwę przed wizerunkiem Marii lub inne zbożne dzieło: T. Hirsch, Die Oberpfarrkirche von St-Marien in ihren Denkmälern und in ihren Beziehungen zum kirchlichen Leben Danzig überhaupt, dargestellt von, Theil 1, Danzig 1843, s. 381-382.

177 H. Belting, Image et culte, s. 595. Powtórzenia dzieł kultowych służyły propagacji sanktuarium, wiązało się z nimi przekonanie o uczestnictwie w mocy prototypu - znane są legendy o powielających się przedstawieniach kultowych lub o cudach, sprawianych przez ich kopie. 
przekazu o Nowej Ewie. Jako Regina Coeli, Maria Bractwa Kapłańskiego wpisuje się w tradycyjny, krzyżacki jeszcze wymiar kultu Marii jako suzerenki na tych ziemiach. Wpisuje się w lokalną tradycję ikonograficzną i utrwala ją $\mathrm{w}$ państwie zakonnym do końca średniowiecza ${ }^{178}$, a nawet do czasów nowożytnych ${ }^{179}$.

Tymczasem w drugiej ćwierci XV wieku pojawił się w Prusach nowy typ wyobrażeń maryjnych, bez wątpienia sięgający do tzw. czeskiej grupy Pięknych Madonn w geście ostensio, który zdominował wyobrażenia maryjne po połowę XV wieku. Reprezentują go przykładowo rzeźby z Obozina, Lichnowów, Niedźwiedzicy, Srokowa. W przeciwieństwie do finezyjnego przekazu wizualnego Pięknej Madonny Toruńskiej, typ ten wyraziście eksponował myśl o eucharystycznie pojętym ciele Chrystusa, a bezpośredniość kontaktu pomiędzy świętymi postaciami a modlącym się wiernym była nie bez znaczenia dla popularności tego ujęcia na pruskiej prowincji. Szła ona w parze $\mathrm{z}$ bardzo znamienną przemianą natury społecznej - narodzinami pobożności ludowej ${ }^{180}$. Pod jej wpływem, w ciągu pierwszej ćwierci XV wieku sposób intymnego obrazowania Marii faktycznie nabrał w Prusach nowego kontekstu - rzeźby Matki Bożej, trzymającej na ręce lub piastującej na kolanach pulchne, nagie Dzieciątko, około 1420 roku stały się tu standardem ${ }^{181}$. Nie było to już jednak zjawisko o charakterze regionalnym, lecz łączyło się z ogólnoeuropejską przemianą kulturową „jesieni średniowiecza". Nawet mimo naiwnego, prowincjonalnego liryzmu, rzeźby te zachowywały na ogół tradycyjną, kultową frontalność kompozycji i funkcjonowały w ołtarzach. Skomplikowane treści i funkcje, jakim

178 Analogiczny wariant (Maria Królowa, upozowana w kontrapoście, niesie na lewym ramieniu Dzieciątko o skrzyżowanych nóżkach), choć z drobnymi przeobrażeniami gestów czy zmianami atrybutów, reprezentują rzeźby późnogotyckie z przełomu XV i XVI wieku w Waplewie, Pęciszewie, Żukowie.

179 K. Wróblewska, Dwie gotyckie rzeźby i ich ludowe naśladownictwo, w: Szkice olsztyńskie, red. J. Jasiński, Olsztyn 1967, s. 61-66.

180 S. Kwiatkowski, Klimat religijny $w$ diecezji pomezańskiej u schyłku XIV i w pierwszych dziesięcioleciach XVw., „Roczniki TNT” 1990, t. 84, z. 1), Toruń 1990, s. 13-34.

181 Wśród Madonn tronujących w nowym ujęciu można wskazać Marię ze Starej Kościenicy (w Muzeum Archidiecezjalnym w Oliwie), figurę w ołtarzu w Sokolicy lub nieznanego pochodzenia Madonny w Muzeum Narodowym w Gdańsku czy w Muzeum Zamkowym w Lidzbarku Warmińskim. 
trzy dekady wcześniej służyła kreacja Pięknych Madonn, ustąpiły więc miejsca kultowej i obrazowej simplicyzacji.

Podsumowując - państwo krzyżackie było zdolne przyjąć zarówno dworską rafinację Pięknej Madonny Toruńskiej, jak i chłodny arystokratyzm Pięknej Madonny Gdańskiej. Było zdolne zachwycić się ich „klasycznym” urokiem (a zachwyt ów trwał jeszcze długo, jak zaświadcza opis kanonika Strzesza). Nie wiemy, na ile pojawianie się tu tych rzeźb było kwestią przypadku, na ile - mody, na ile - świadomej fundacji. Z pewnością zaistniały one w określonym klimacie kulturowym, na styku tradycyjnego kultu maryjnego i nowej pobożności, dając świadectwo przemianom w życiu religijnym pruskich miast. Nie dysponując potwierdzonymi danymi na temat ich pierwotnego usytuowania, o intelektualnej i estetycznej kondycji środowisk, w których funkcjonowały, możemy snuć tylko domysły. Państwo krzyżackie nie odegrało jednak żywej roli w wypracowaniu ani rozwoju tego typu przedstawień. Ich pojawienie się było raczej aktem wyboru i recepcji niż koncepcji i kreacji. Liczne lokalne przeobrażenia kultowego modelu Madonny Bractwa Maryjnego, nawiązania do typu Madonny w geście ostensio czy inne powielane w snycerstwie prowincjonalnym warianty wyobrażeń maryjnych, wiązały się nie z twórczym przetwarzaniem, lecz z powtarzaniem i standaryzacją pewnej obiegowej już formy. Jako grupa typologiczna i kompleks formalny, Piękne Madonny były w Prusach zjawiskiem raczej wyizolowanym. Podjęta tu próba analizy ujawnia, że także z punktu widzenia badań regionalnych problem tego kręgu stylowego przynosi więcej pytań bez odpowiedzi niż konkretnych rozwiązań. Wbrew najnowszej literaturze, ich rola artystyczna - jako domniemanej kwintesencji stylu międzynarodowego w Prusach - nie daje się uchwycić, a kwestia rzeczywistego znaczenia jako świadectwa pobożności pozostaje otwarta. 


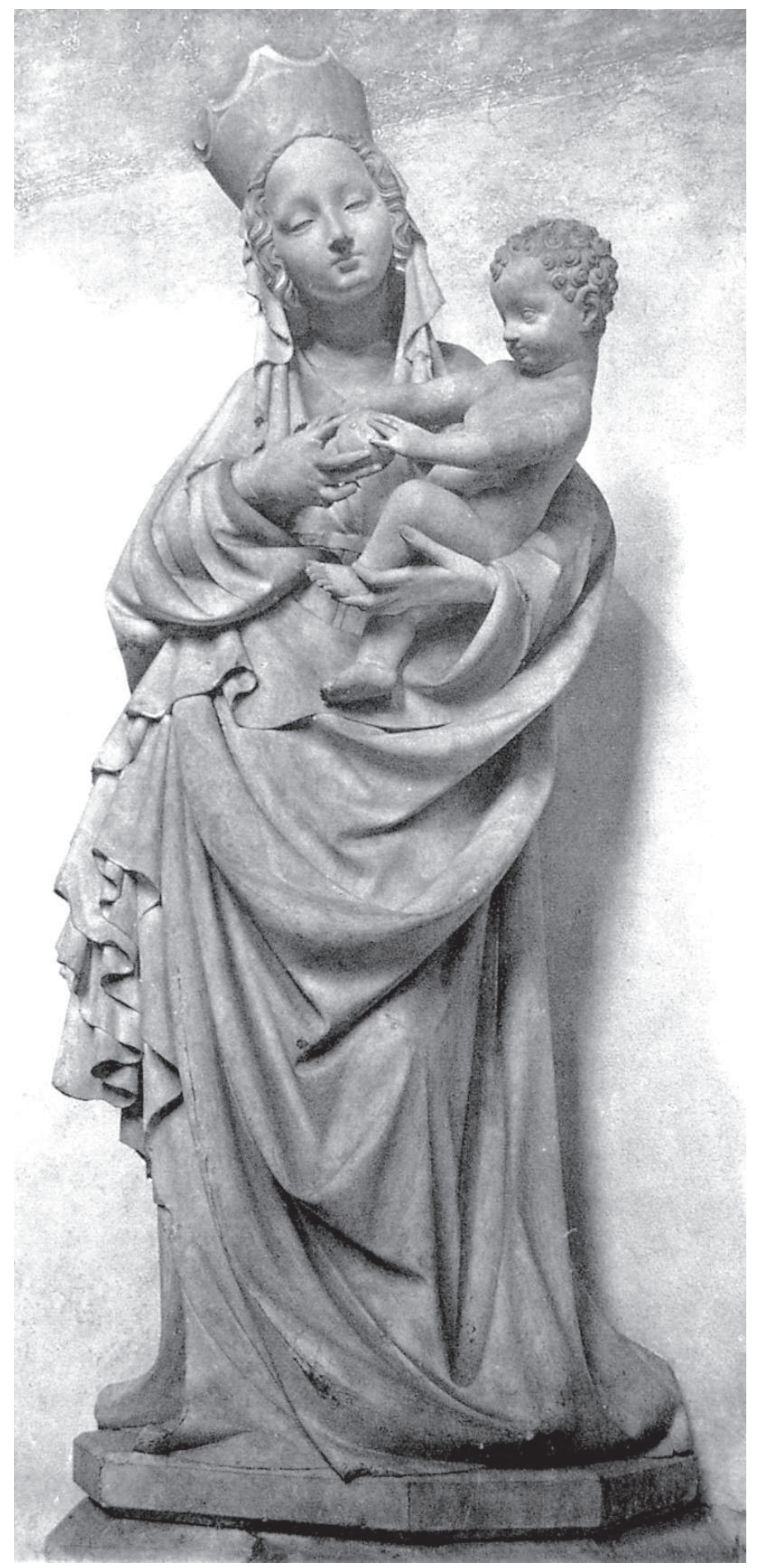

Il. 1. Piękna Madonna Toruńska, Praga, ok. 1390 r., kościół św. Jana w Toruniu - zaginiona (fot. według: K. H. Clasen, Die mittelalterliche Bildhauerkunst, il. 152) 


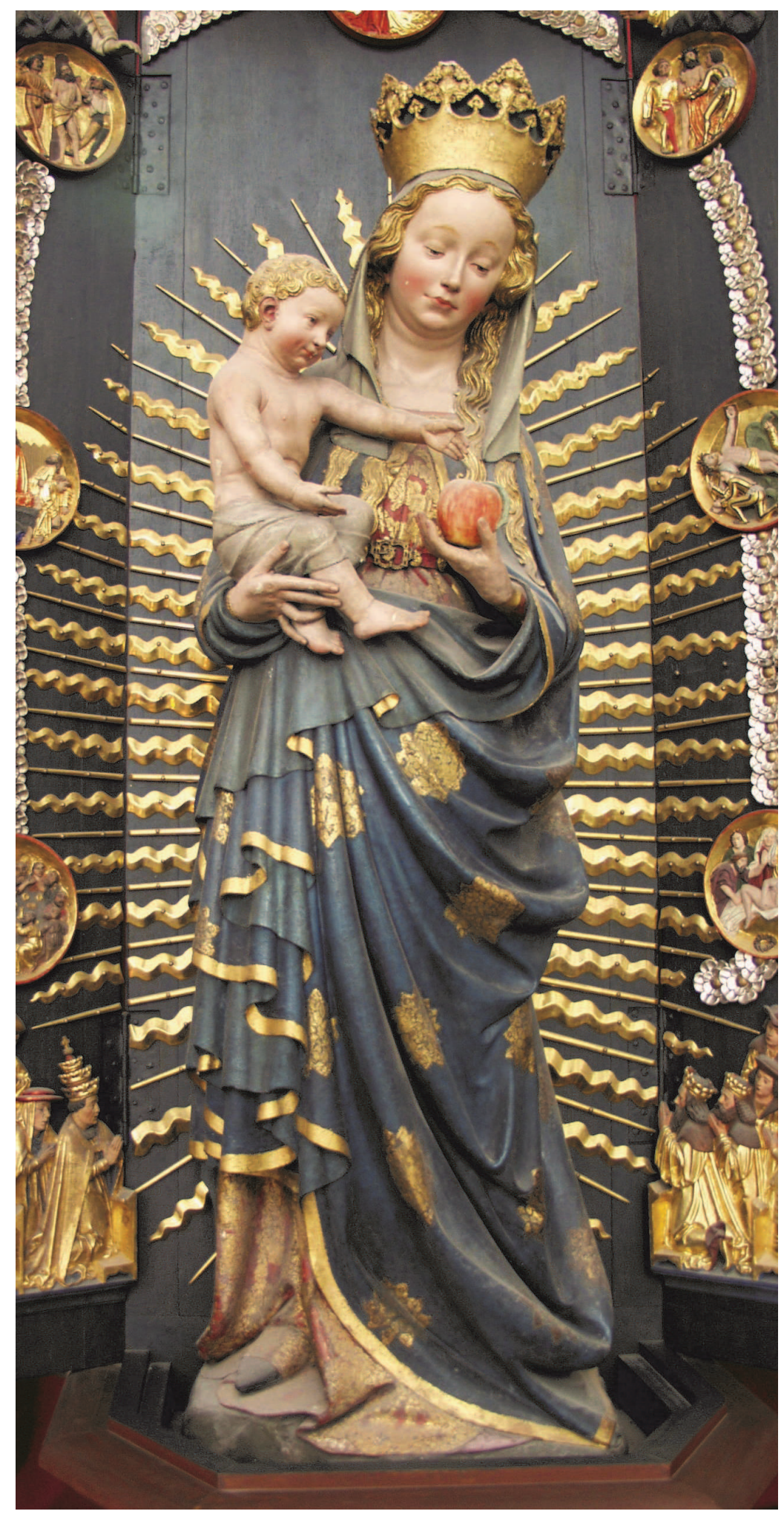

Il. 2. Piękna Madonna Gdańska, Gdańsk, ok. 1430 r., kościół NMP w Gdańsku (fot. J. Raczkowski) 


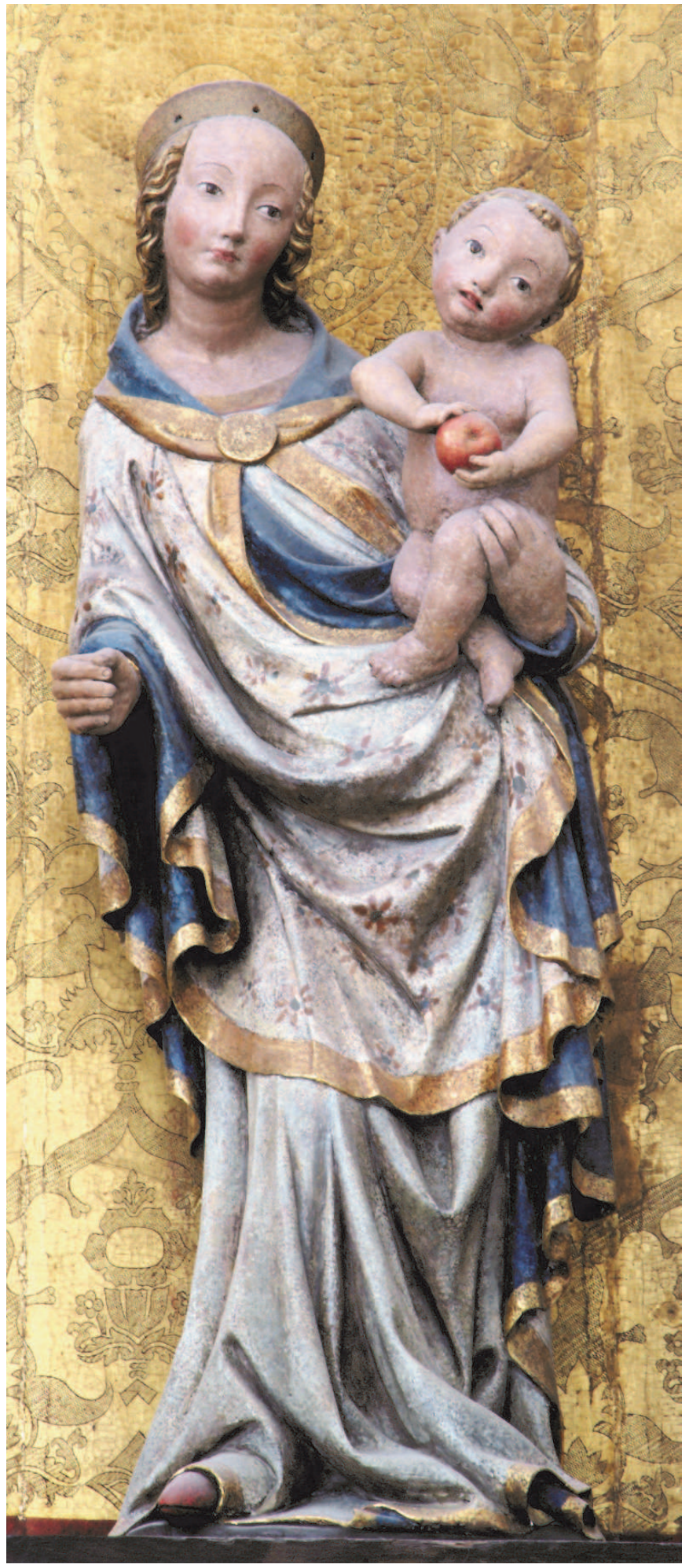

Il. 3. Piękna Madonna Bractwa Maryjnego, Praga, ok. 1400 r., kościół NMP w Gdańsku (fot. J. Raczkowski) 


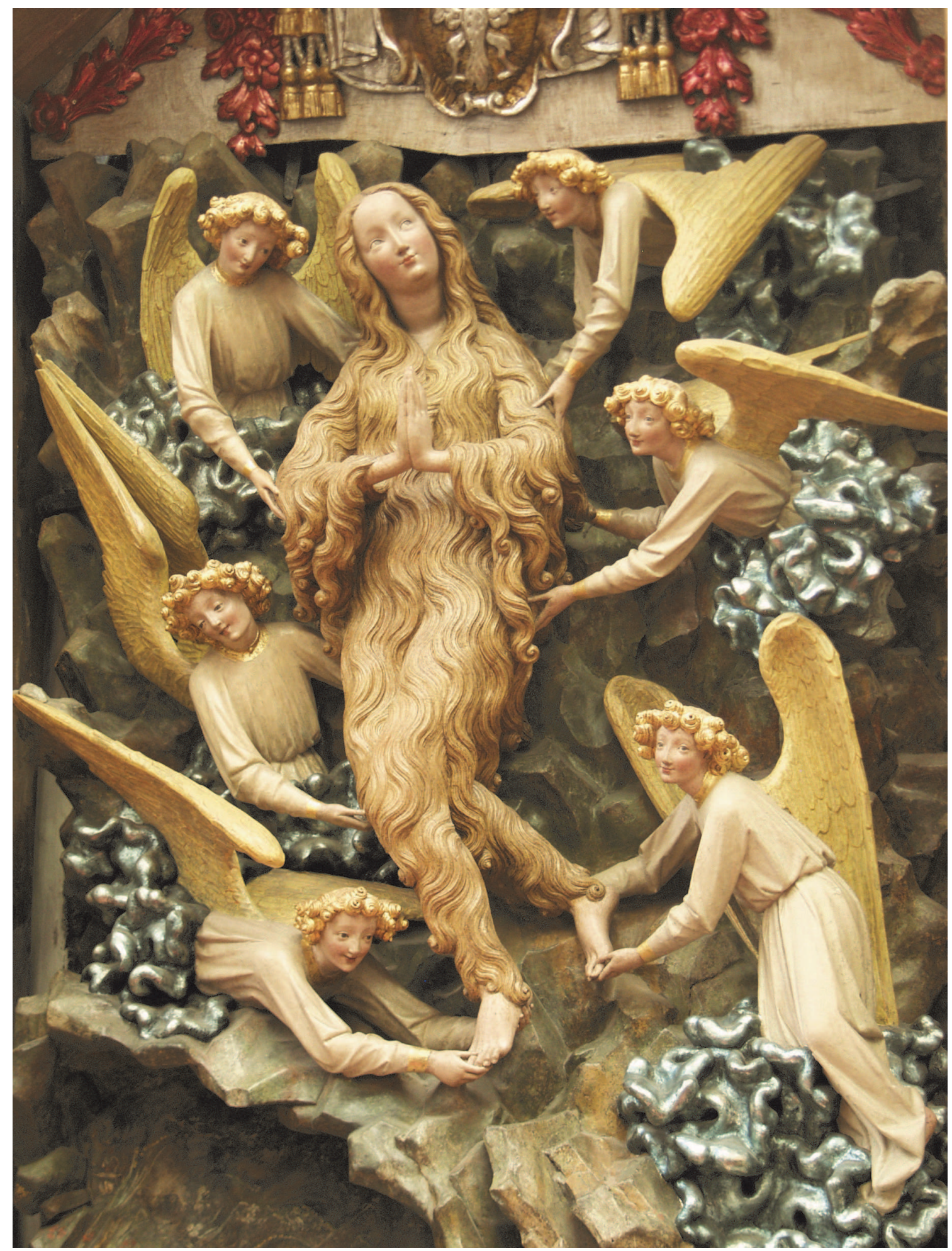

Il. 4. Wniebowzięcie (Ekstaza) św. Marii Magdaleny, Toruń, po 1416 r., kościół św. Jana w Toruniu (fot. J. Raczkowski) 


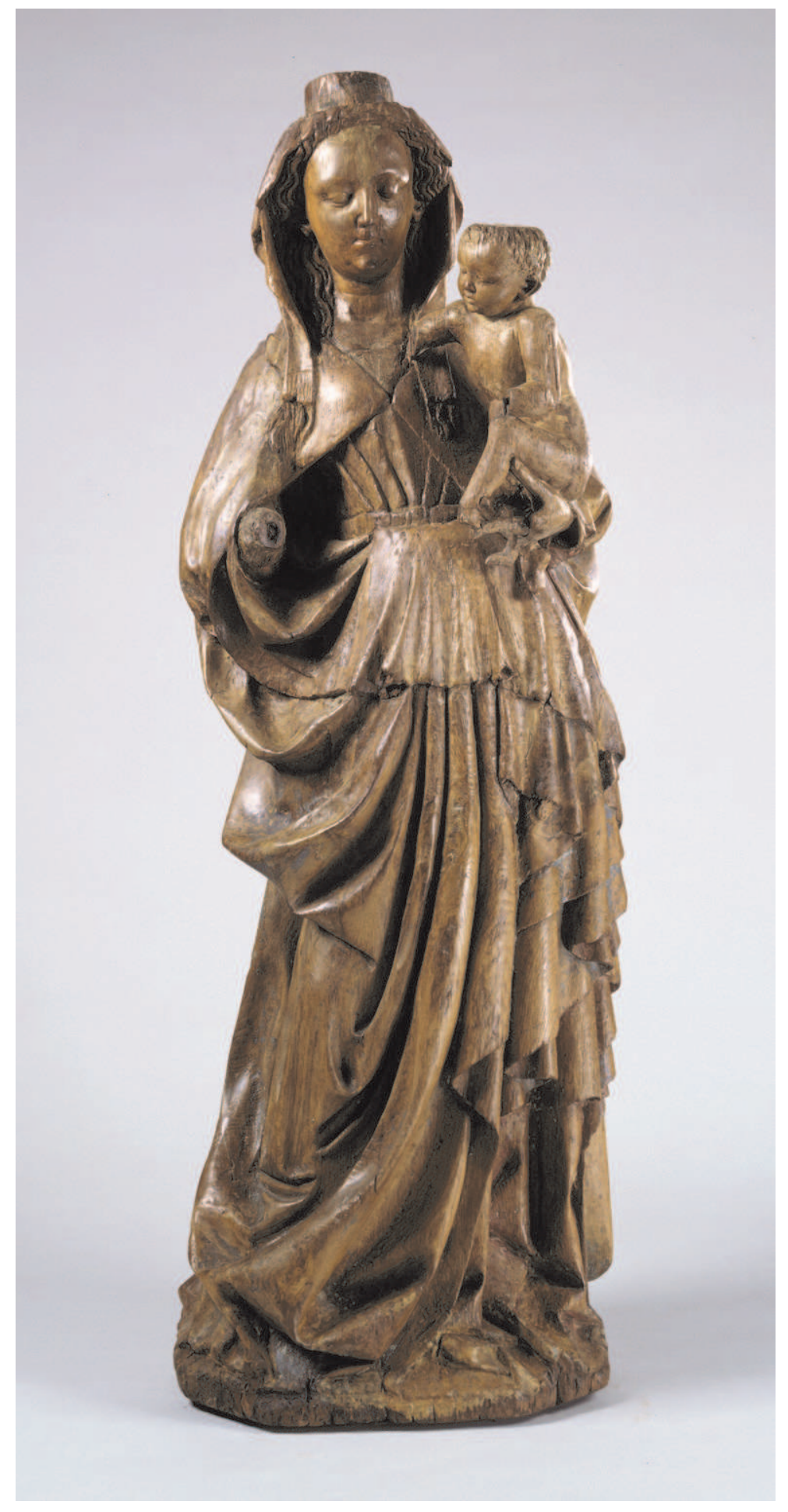

Il. 5. Madonna $\mathrm{z}$ Dzieciątkiem $\mathrm{Z}$ Ankeveen, Utrecht, ok. 1430-1435 r., Rijskmuseum Het Catharijnekonvent w Utrechcie, nr inw. ABM bh 494 (fot. Rijskmuseum) 


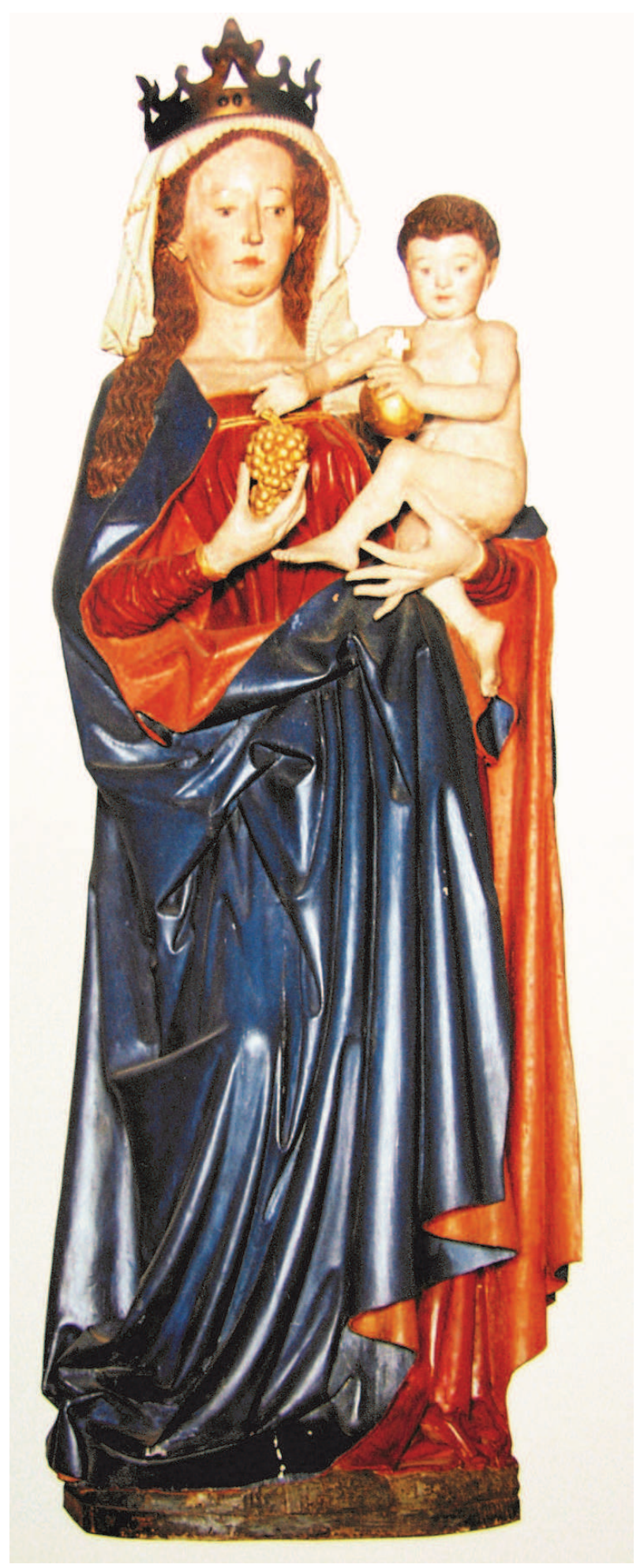

Il. 6. Madonna z Dzieciątkiem z kościoła św. Macieja w Trewirze, 1450-1460 (fot. według: Late Gothic Sculpture, s. 295) 


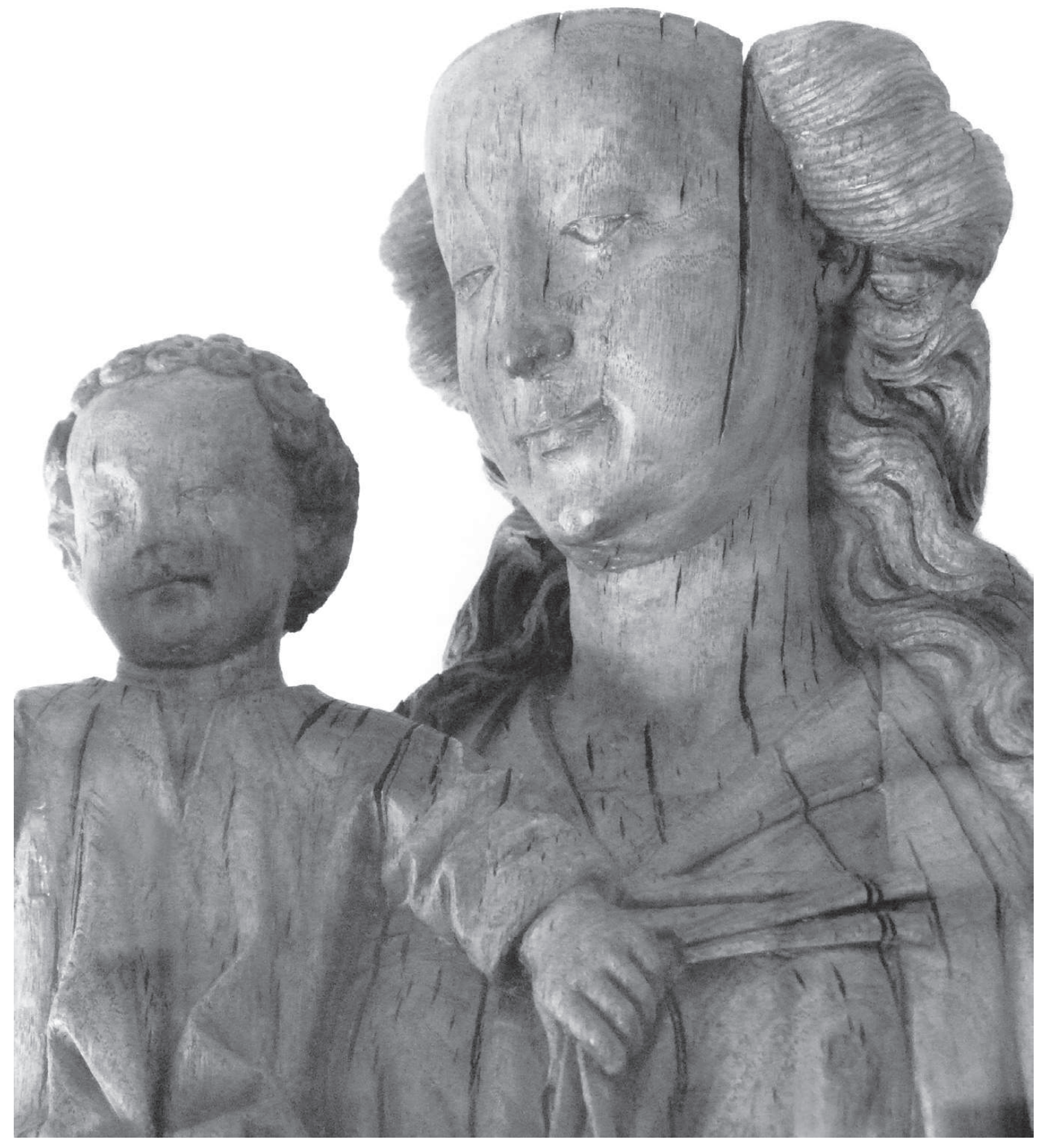

Il. 7. Jan Nude, Madonna z Dzieciątkiem, ok. 1470-1480, Musée du Louvre w Paryżu, nr inw. RF 2319 - fragment (fot. M. Jakubek-Raczkowska) 


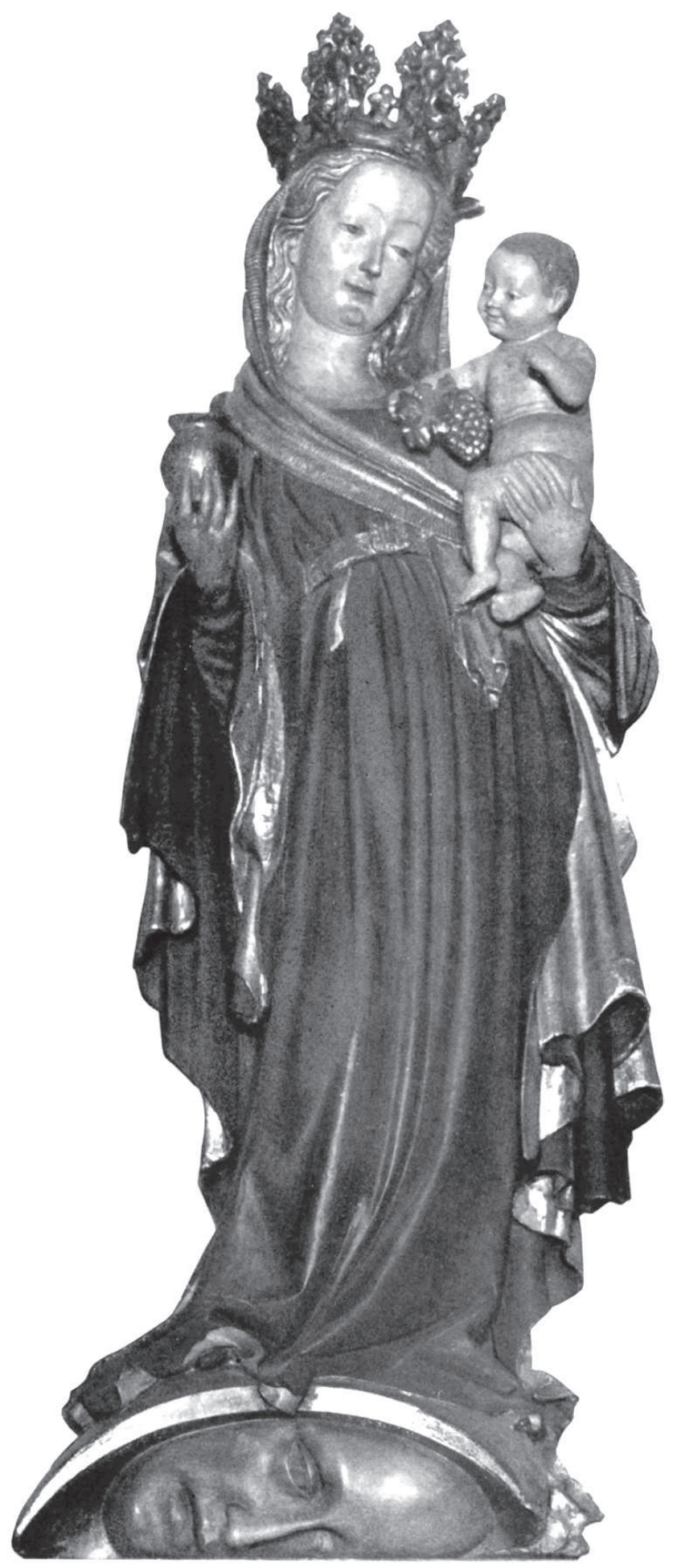

Il. 8. Madonna z Dzieciątkiem z kościoła par. w Hallgarten, 1415-1420 (fot. według: Kunst um 1400 am Mittelrhein, s. 152) 


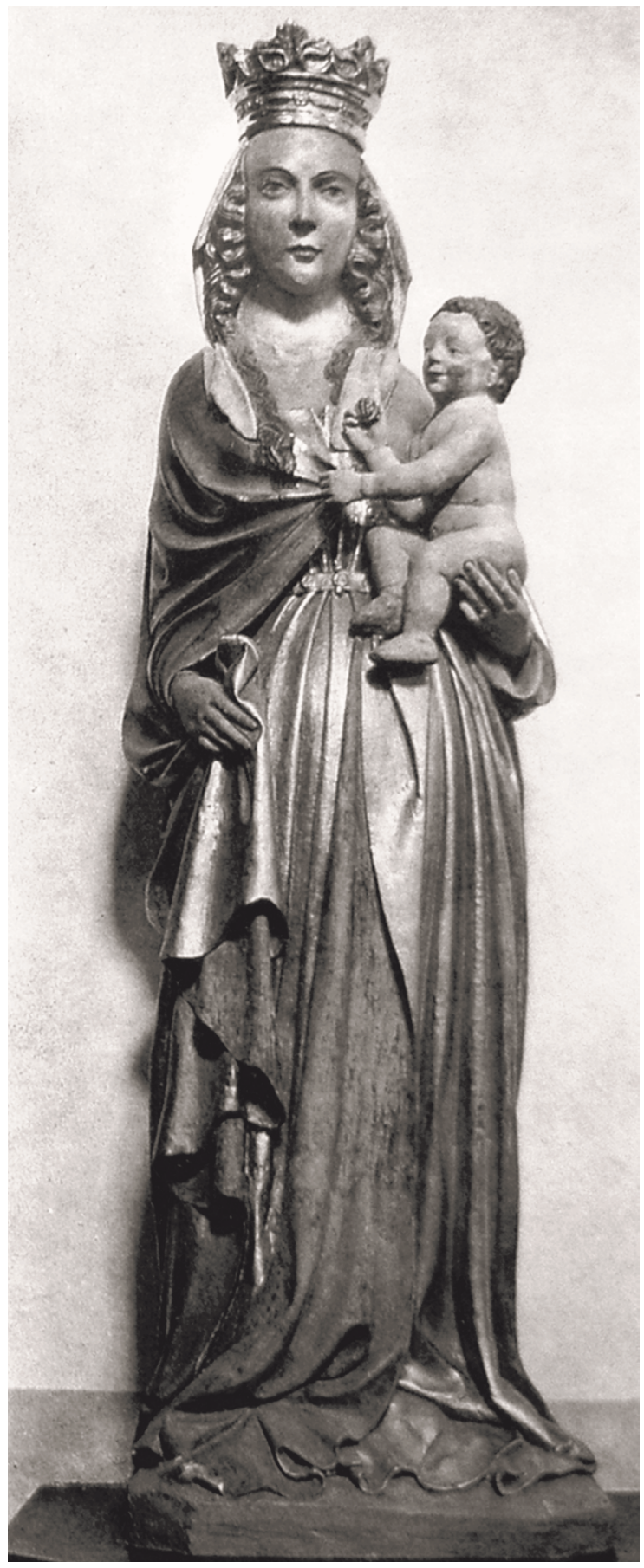

Il. 9. Madonna z Dzieciątkiem z katedry we Fromborku, Gdańsk, ok. 1420-1430 r., Muzeum Mikołaja Kopernika we Fromborku, stan sprzed 1945 r. (fot. według: K. H. Clasen, Die mittelalterliche Bildhauerkunst, il. 368) 


\section{Summary}

\section{Some remarks to the significance of the so-called Beautiful Madonnas in the art and religiosity of the Teutonic State in Prussia}

The so-called Beautiful Madonnas belong among the most interesting and the most complex groups in Gothic sculpture, being still subject to vivid discussions - despite the apparent depletion of the discourse. Time and again new attempts of defining those sculptures emerge, both in terms of their message and their visual structure; new attempts to approach their systematics and attribution. Having a crucial significance for the artistic evolution of Central Europe at the dawn of 15th century, they became an axis of one of more important discussions in Mediaeval studies of that region: the dispute on the genesis of International Style, which keeps reappearing and arising controversies.

In Prussia the circle of Beautiful Madonnas has been represented by three figures - the missing Beautiful Madonna on the Moses-console from St. John's church in Toruń, the Gdańsk Beautiful Madonna in the Rosary Retable in Holy Virgin Church in Gdańsk and located in the same church Virgin with The Child in the Priestly Brotherhood Retable. Despite the previously proposed systematics, none of them seems to be of local creation in the land of former Teutonic State. It also seems that there is no direct relation between them. In this paper a question is being asked about artistic significance of those sculpture for the art of the region (the creativity of local environment) and about their functional sense.

After the period of numerous polemics - especially in context of Clasen's work - presently it is accepted that Beautiful Madonnas are the efflorescence of the experience of Bohemian art. The figure from Torun not only originated from the Bohemian tradition (which had been repeatedly underlined), but most probably it had been made in one of Prague workshops and found its way to Prussia by import. It has been confirmed by its typological isolation (the lack of similar images of Virgin Mary, that would suggest assimilation of the formula) and 
artistic alienation in the art of the region. One can not find any justification for most of the so far attributions, relating other eminent works to the Torun master: Christ in Gethsemane made of marly limestone (Pläner Kalkstein) is an import from Prague, as well as a different in form, missing Mary of Good Hope. Also the attribution of a relief Assumption of Mary Magdalene does not seem convincing. The circle of the supposed followers of the master is also disputable. One can not find justification especially for the proposal to relate much younger (ca. 1430) figure of the so-called Gdańsk Beautiful Madonna with the one from Torun. The Gdańsk sculpture originates from different, French tradition and reveals North-Netherland workshop affiliations (the Ankeveen Madonna). Due to its large dimensions one can assume, that is was made on site. Perhaps the same workshop produced also the so far omitted, partly damaged Madonna in the Frombork Cathedral, that underwent conservation treatment in 2008-2009. It is hard to determine, whether the Netherland master brought to Gdańsk an already formed topos of western art, or whether he worked it out in Gdańsk (in relation with the model of Beautiful Madonna from Toruń). The further development of his art took place most probably not in Pomerania, but in the North Netherlands. And finally the sculpture in the Holy Virgin Brotherhood Retable - another example of an import from Prague, in terms of form reaching for the patterns of late $14^{\text {th }}$ century, in terms of type belonging to the times after 1400 . Only this one became a subject of local reception, most probably due to its cult (indulgence) function and the miraculous air.

Thus Prussian Beautiful Madonnas were imports from abroad, and not the efflorescence of local artistic tendencies. As a typological and stylistic group they remained an isolated phenomenon in Orderly State. They emerged in a specific religious climate, on the verge of traditional cult of Virgin Mary and devotio moderna, giving witness to the transformations of religious life in Prussia. However, since their artistic impact - as a type, a model, a stylistic source - was not very big, the question of their real significance as a testimony of religious devotion remains open.

Translated by Joanna M. Arszyńska 